\title{
Article \\ Toxicological and Nutraceutical Screening Assays of Some Artificial Sweeteners
}

\author{
Marcos Mateo-Fernández ${ }^{1}$, Miguel Josué González-Jiménez ${ }^{1}$, Mercedes Del Río Celestino ${ }^{2}{ }^{\circledR}$, Rafel Font ${ }^{2}$, \\ Ángeles Alonso-Moraga ${ }^{1}$ and Tania Merinas-Amo ${ }^{1, * \mathbb{C}}$
}

1 Department of Genetics, University of Córdoba, 14071 Córdoba, Spain; mmateo@ceslopedevega.com (M.M.-F.); mjgonzalezjimenez3@gmail.com (M.J.G.-J.); ge1almoa@uco.es (Á.A.-M.)

2 Agri-Food Laboratory, CAGPDS, Avd. Menéndez Pidal, s/n, 14080 Córdoba, Spain; mercedes.rio.celestino@juntadeandalucia.es (M.D.R.C.); rafaelm.font@juntadeandalucia.es (R.F.)

* Correspondence: tania.meram@gmail.com or b32meamm@uco.es; Tel.: +34-957218674; Fax: +34-957212072

check for updates

Citation: Mateo-Fernández, M.;

González-Jiménez, M.J.; Celestino, M.D.R.; Font, R.; Alonso-Moraga, Á.; Merinas-Amo, T. Toxicological and Nutraceutical Screening Assays of Some Artificial Sweeteners. Processes 2022, 10, 410. https://doi.org/10.3390/ pr10020410

Academic Editor: Bing-Huei Chen

Received: 22 January 2022

Accepted: 16 February 2022

Published: 20 February 2022

Publisher's Note: MDPI stays neutral with regard to jurisdictional claims in published maps and institutional affiliations.

Copyright: (C) 2022 by the authors. Licensee MDPI, Basel, Switzerland. This article is an open access article distributed under the terms and conditions of the Creative Commons Attribution (CC BY) license (https:// creativecommons.org/licenses/by/ $4.0 /)$.

\begin{abstract}
Artificial sweeteners are food additives worldwide used instead of fructose or glucose in many diet beverages. Furthermore, diet beverages intake has been increasing every year. Thus, some food agencies should regulate it based on toxicological studies. Debates and controversial results are demonstrated, and authority can revise its decision on the basis of new data reporting toxicological effects since cyclamate has been forbidden in some countries. Therefore, the aim of this study was to report new data about the toxicity of acesulfame-k, aspartame, and cyclamate, which are useful for authority agencies, determining the toxic potential and nutraceutical capabilities of these compounds. The toxicity, antitoxicity, genotoxicity, antigenotoxicity, and life expectancy assays were carried out in Drosophila as an in vivo model. In addition, in vitro HL-60 line cell was used to evaluate the chemopreventive activity determining the cytotoxic effect and the capability of producing DNA damage due to internucleosomal fragmentation or DNA strand breaks. Furthermore, the methylated status of these cancer cells treated with the tested compounds was assayed as a cancer therapy. Our results demonstrated that all tested compounds were neither toxic nor genotoxic, whereas these compounds resulted in antigenotoxic and cytotoxic substances, except for cyclamate. Aspartame showed antitoxic effects in Drosophila. All tested compounds decreased the quality of life of this in vivo organism model. Acesulfame-k, aspartame, and cyclamate induced DNA damage in the HL-60 cell line in the comet assay, and acesulfame-k generally increased the methylation status. In conclusion, all tested artificial sweeteners were safe compounds at assayed concentrations since toxicity and genotoxicity were not significantly induced in flies. Moreover, Aspartame and Cyclamate showed protective activity against a genotoxin in Drosophila Regarding nutraceutical potential, acesulfame-k and aspartame could be demonstrated to be chemopreventive due to the cytotoxicity activity shown by these compounds. According to DNA fragmentation and comet assays, a necrotic way could be the main mechanism of death cells induced by acesulfame-k and aspartame. Finally, Acesulfame-K hypermethylated repetitive elements, which are hypomethylated in cancer cells resulting in a benefit to humans.
\end{abstract}

Keywords: acesulfame-k; aspartame; cyclamate; Drosophila melanogaster; HL-60 cell line; toxicological assays

\section{Introduction}

Artificial sweeteners are food additives worldwide used as sugar substitutes in beverages, being sweeter than table sugar and with fewer calories [1,2]. As their intake has been increasing every year, some food agencies (FDA-Food and Drug Administration, EFSAEuropean Food Safety Authority) are responsible for regulating their safe intake. Despite there being many studies determining their carcinogenicity and toxicity, food agencies 
do not support that relationship. Actually, a review of the role of artificial sweeteners on human metabolism reports that these sweeteners are not beneficial as they are used in diets since non-caloric sweeteners induce an increase in appetite [3,4]. In addition, artificial sweeteners are related to different kinds of human diseases, but cancer is not generally demonstrated to be provoked by artificial sweeteners [5]. Debates and controversial results are demonstrated, and the authority can revise its decision on the basis of new data reporting toxicological effects $[6,7]$.

Aspartame (ASP), Cyclamate (CYC), and Acesulfame-potassium (ACK) are used instead of fructose and glucose as sweeteners without providing energy in diet beverages, being 300 times sweetener than sugar. Besides the controversial information of artificial sweeteners, CYC has been forbidden in many countries [8], although evidence of CYC carcinogenicity was not found [9]. ASP and ACK have been demonstrated to be deregulators of gut microbiota which is related to obesity $[10,11]$. Moreover, deregulation of the energetic balance of the metabolism could be involved in the cancerous process [12]. The combination of ACK intake and diet foods affects the cognitive function in mice [13].

Toxicological and genotoxicological tests have been used all over the world to evaluate the potential risk of food [14]. In addition, in vivo and in vitro clastogenicity and antigenotoxicity tests must be performed to evaluate the nutraceutical potential of food since the "initiation" step of tumorigenesis involves alterations of the genetic material, which are called "genotoxic" and are assessed by different end-points as DNA-strand breaks and mutation induction which must be stabilised/reverted [15].

With this in mind, the Somatic Mutation and Recombination Test (SMART) is frequently assayed using the in vivo Drosophila melanogaster model to determine somatic cell mutations, widely associated with mutagenicity and cancer $[16,17]$, and it allows for detecting the genotoxic and antigenotoxic activity of single compounds [18,19]. Fly models are also widely used to analyse the longevity parameters due to the high homology between invertebrates and human genes involved in the ageing process [20,21]. On the other hand, toxicity, necrosis, apoptosis and methylation status in chemoprevention processes are evaluated using cytotoxicity, DNA damage at both internucleosomal fragmentation and at single/double-strand breaks assays, and biomarkers of genomic DNA methylation in HL-60 promyelocytic cells [22-24].

Therefore, the aim of this study is to produce new data about the toxicity of ASP, CYC and ACK, which is useful for authority agencies, determining the toxic potential and nutraceutical capabilities of these compounds. The toxicity, antitoxicity, genotoxicity, antigenotoxicity and life expectancy assays were carried out in Drosophila as an in vivo model. In addition, in vitro HL-60 line cell was used to evaluate the chemopreventive activity determining the cytotoxic effect and the capability of producing DNA damage due to internucleosomal fragmentation or DNA strand breaks. Furthermore, the methylated status of these cancer cells treated with the tested compounds was assayed as a cancer therapy.

\section{Materials and Methods}

\subsection{Samples}

Artificial sweeteners, ASP (E-951- L-aspartyl-L-phenylalanine methyl ester), CYC (sodium salt of cyclohexylsulfamic acid) and ACK (potassium salt of 6-methyl-1,2,3oxathiazinone-2,2-dioxide) were assayed. ASP, CYC and ACK were obtained from TCI America (228 39-47-0) (Portland, OR, USA), ACROS Organics (Geel, Belgium) (139-05-9) and TCI America (55589-62-3), respectively.

\subsection{Fly Stocks}

Two Drosophila melanogaster strains with genetic markers that affect the wing-hair phenotype were used: (i) $m w h / m w h$, carrying the recessive mutation $m w h$ (multiple wing hairs) [25], and (ii) $f l r^{3} / \operatorname{In}(3 L R) T M 3$, rip $^{p}$ sep $b x^{34 e} e^{s} B d^{S}$, where the $f l r^{3}$ (flare) [26] marker is a homozygous recessive lethal mutation which is viable in homozygous somatic cells once larvae start developing and producing deformed trichomas. 


\subsection{Cell Culture Conditions}

Promyelocytic human leukaemia (HL-60) cells were grown in RPMI-1640 medium (Sigma, R5886, Sigma Aldrich, Gillingham, UK) supplemented with heat-inactivated foetal bovine serum (Linus, S01805, Madrid, Spain), L-glutamine $200 \mathrm{mM}$ (Sigma, G7513) and $1 \mathrm{X}$ antibiotic-antimycotic solution (Sigma, A5955). Cells were incubated at $37{ }^{\circ} \mathrm{C}$ in a humidified atmosphere of $5 \% \mathrm{CO}_{2}$. Cultures were plated at $2.5 \times 10^{4}$ cells $/ \mathrm{mL}$ density in $10 \mathrm{~mL}$ culture bottles and passed every 2 days.

\subsection{In Vivo Assays}

\subsubsection{Toxicity and Antitoxicity Assays}

Toxicity was assayed according to our standard protocols. The concentrations used in ASP and ACK were $0.0063 \mathrm{mM}, 0.025 \mathrm{mM}, 0.05 \mathrm{mM}, 0.2 \mathrm{mM}$ and $0.815 \mathrm{mM}$; and $0.0125 \mathrm{mM}$, $0.05 \mathrm{mM}, 0.1 \mathrm{mM}, 0.4 \mathrm{mM}$ and $1.6 \mathrm{mM}$ in the CYC assays, according to previous analyses carried out by Lehkorizova, et al. [27] and Cillo [8]. Negative $\left(\mathrm{H}_{2} \mathrm{O}\right)$ and positive $(0.15 \mathrm{M}$ $\mathrm{H}_{2} \mathrm{O}_{2}$ ) toxicant concurrent controls were also assayed, according to the previous ranges established by Romero-Jiménez et al. [28]. Larvae fed with Drosophila Instant Medium (Formula 4-24, Carolina Biological Supply, Burlington, NC, USA) supplemented with the concentrations of the assessed compounds were used as tested groups. The percentage of emerging adults was calculated by comparing each treatment with the negative control. The antitoxic effect of tested compounds was assessed following the same method as toxicity assays but in combined treatments with $0.15 \mathrm{M} \mathrm{H}_{2} \mathrm{O}_{2}$ and comparing the percentage of emerging adults with the positive toxicant control [29].

\subsubsection{Genotoxicity and Antigenotoxicity Assays}

Genotoxicity assays were carried out following the wing spot test standard procedure [16]. Briefly, after crossing two-fold four day-old virgin $\mathrm{flr}^{3}$ females with $m$ wh males (2:1 respectively), trans-heterozygous larvae for both genes were obtained. Four days after fertilisation, a fresh yeas medium ( $25 \mathrm{~g}$ yeast and $4 \mathrm{~mL}$ sterile distilled water) was used to lay eggs for $8 \mathrm{~h}$ focusing on obtaining synchronised larvae. After $72 \mathrm{~h}$, larvae were washed and collected in groups of 100 individuals. Each group was fed with a mixture containing $0.85 \mathrm{~g}$ Drosophila Instant Medium (Formula 4-24, Carolina Biological Supply, Burlington, NC, USA) and $4 \mathrm{~mL}$ water supplemented with the different compounds and concentrations assayed and negative $\left(\mathrm{H}_{2} \mathrm{O}\right)$ and positive $\left(0.15 \mathrm{M} \mathrm{H}_{2} \mathrm{O}_{2}\right)$ controls until pupae hatching (10-12 days). Then, emerged flies were collected and stored in 70\% ethanol until the wings were isolated and mounted on slides using Faure's solution. Mutant spots were assessed in both dorsal and ventral surfaces of the wings in a bright light microscope at $400 \times$ magnification. The frequencies of each type of mutant clone per wing (single, large or twin spot) were compared with the concurrent negative control [30]. All inconclusive and positive results $(p>0.05)$ were analysed with the nonparametric U-test of Mann, Whitney and Wilcoxon $(\alpha=\beta=0.05)$.

Antigenotoxicity tests were conducted following the method previously described by Anter et al. [31]. The same compounds and concentrations were assayed in combined treatment with the concurrent genotoxicant hydrogen peroxide $(0.15 \mathrm{M})$. Single and twin spots per wing were also recorded and compared with the concurrent negative control as described before. Finally, the inhibition percentages (IP) for the combined treatments were calculated as described by Abraham [32]: IP $=$ [(genotoxin alone - combined treatment)/genotoxin alone] $\times 100$.

\subsubsection{Chronic Treatments: Lifespan and Healthspan Assays}

F1 progeny from mwh and $\mathrm{flr}^{3}$ parental strains produced by $24 \mathrm{~h}$ egg-laying in yeast was used for all the longevity trials. The same compounds and concentrations as in the toxicity/genotoxicity experiments were assayed. Lifespan assays were carried out at $25{ }^{\circ} \mathrm{C}$ according to the procedure described by Fernandez-Bedmar et al. [19]. Briefly, once emerged adults were obtained from pupae following a similar method from genotoxicity 
assay; they were collected under $\mathrm{CO}_{2}$ anaesthesia and placed in groups of 25 individuals of the same sex into sterile vials containing $0.21 \mathrm{~g}$ Drosophila Instant Medium and $1 \mathrm{~mL}$ of different concentrations of the compounds to be chronically tested. The number of survivors was determined twice a week in three different replicates.

\subsection{In Vitro Assays}

\subsubsection{Cytotoxicity Assays}

Trypan blue test was used to determine the effect of our tested compounds on cell viability according to our standard procedures [31]. HL-60 cells were placed in 96 well plates $\left(2 \times 10^{4}\right.$ cells $\left./ \mathrm{mL}\right)$ and cultured for $72 \mathrm{~h}$ supplemented with 5 different concentrations of ASP, CYC and ACK. The cytotoxic inhibitory concentration $50\left(\mathrm{IC}_{50}\right)$ was estimated from these concentrations. After culture, trypan blue dye (Sigma, T8154) was used to stain cells with a 1:1 volume ratio and counted in a Neubauer chamber at $100 \times$ magnification. The survival percentage of each treatment compared with the control was recorded in three independent replicates.

\subsubsection{DNA Fragmentation Status}

The determination of DNA damage by internucleosomal DNA fragmentation induction was described by Anter et al. [33]. Briefly, $10^{6} \mathrm{HL}-60$ cells were co-cultured with 5 same concentrations of ASP, CYC, and ACK selected in the cytotoxicity assays for $5 \mathrm{~h}$. After treatment, genomic DNA was extracted using a commercial kit (Blood Genomic DNA Extraction Mini Spin Kit, Canvax Biotech, Córdoba, Spain). Then, DNA was incubated overnight with RNase at $37^{\circ} \mathrm{C}$ and quantified in a spectrophotometer (Nanodrop ${ }^{\circledR}$ ND1000). Finally, $1200 \mathrm{ng}$ DNA were electrophoresed in a $2 \%$ agarose gel for $120 \mathrm{~min}$ at $50 \mathrm{~V}$, stained with ethidium bromide and visualised under UV light. The apoptosis process is recognised by the appearance of internucleosomal DNA fragments that are multiples of 200 base pairs.

\subsubsection{Clastogenicity: SCGE (Comet Assay)}

DNA stability was determined by SCGE as described by Mateo-Fernández et al. [34] with minor modifications. HL-60 cells $\left(5 \times 10^{5}\right)$ were incubated in $1.5 \mathrm{~mL}$ of culture medium supplemented with the three lowest concentrations of ASP, CYC, and ACK selected in the cytotoxicity assays, for $5 \mathrm{~h}$. After treatment, cells were washed twice and adjusted to $6.25 \times 10^{5}$ cells $/ \mathrm{mL}$ in PBS (phosphate-buffered saline). Then, a 1:4 dilution from cells in liquid low-melting-point agarose (A4018, Sigma) was prepared at $40^{\circ} \mathrm{C}$ and poured into slides to prepare electrophoresis gels. Gels were covered with a coverslip and allowed to solidify at RT for $30 \mathrm{~min}$. Once the slides solidified, the coverslips were carefully removed, and slides were bathed in freshly prepared lysing solution $(2.5 \mathrm{M} \mathrm{NaCl}, 100 \mathrm{mM}$ Na-EDTA, $10 \mathrm{mM}$ Tris, $250 \mathrm{mM} \mathrm{NaOH}, 10 \%$ DMSO and 1\% Triton $\mathrm{X}-100 ; \mathrm{pH}=13$ ) for $1 \mathrm{~h}$ at $4{ }^{\circ} \mathrm{C}$. Thereafter, slides were balanced in alkaline electrophoresis buffer containing $300 \mathrm{mM} \mathrm{NaOH}$ and $1 \mathrm{mM} \mathrm{Na-EDTA}, \mathrm{pH}=13$ for $20-30 \mathrm{~min}$ at $4{ }^{\circ} \mathrm{C}$. Once equilibrated, the slides underwent electrophoresis $(12 \mathrm{~V}, 400 \mathrm{~mA}$ for $8 \mathrm{~min}$ ) in dark conditions and were immediately neutralised in cold neutral solution ( $0.4 \mathrm{M}$ Tris- $\mathrm{HCl}$ buffer, $\mathrm{pH} 7.5)$ for 10 min. Finally, slides were dried overnight at RT in the dark. Gels were stained with $7 \mu \mathrm{L}$ propidium iodide, and a Leica DM2500 microscope was used to photograph cells at $400 \times$ magnification. At least 50 single cells from each treatment were analysed using the Open CometTM 1.3 software [35]. The Tail Moment (TM) data was used to analyse the effect of the tested compounds on HL-60 cell DNA integrity applying one-way ANOVA and post-hoc Tukey's test with SPSS Statistics for Windows, Version 19.0 (IBM 2010).

\subsubsection{Methylation Status of HL-60 Cells}

The same concentrations of ASP, CYC and ACK described in the SMART assay were used to treat HL-60 cells for $5 \mathrm{~h}$. DNA was extracted following the protocol described in the DNA fragmentation assay. Then, the DNA was converted with bisulphite (EZ 
DNA Methylation-Gold ${ }^{\mathrm{TM}}$ Kit, Zymo Research, Irvine, CA, USA). Bisulphite-modified DNA was used for fluorescence-based real-time quantitative Methylation-Specific PCR (qMSP) using $5 \mu \mathrm{M}$ of each forward and reverse primer (Isogen Life Science BV, Utrecht, The Netherlands), $2 \mu \mathrm{L}$ of iTaq $^{\mathrm{TM}}$ Universal SYBR ${ }^{\circledR}$ Green Supermix (Bio-Rad Laboratories, Hercules, CA, USA) (it contains antibody-mediated hot-start iTaq DNA polymerase, dNTPs, $\mathrm{MgCl}_{2}, \mathrm{SYBR}^{\circledR}$ Green I dye, enhancers, stabilisers and a blend of passive reference dyes including ROX and fluorescein) and $25 \mathrm{ng}$ of bisulphite converted genomic DNA.

QMSP was carried out in triplicate for each compound following the steps established by our research group in similar studies [36]. The housekeeping Alu-C4 was used as a reference to correct for total DNA input. Further information about repetitive elements is shown in Table 1.

Table 1. Primers information [37].

\begin{tabular}{|c|c|c|}
\hline Primer & Forward Primer Sequence $5^{\prime}$ to $3^{\prime}(\mathrm{N})$ & Reverse Primer Sequence $5^{\prime}$ to $3^{\prime}(\mathrm{N})$ \\
\hline ALU-C4 & GGTTAGGTATAGTGGTTTATATTTGTAATTTTAGTA $(-36)$ & ATTAАСТАААСТААТСТТАААСТССТААССТСА (-33) \\
\hline ALU-M1 & ATTATGTTAGTTAGGATGGTTTCGATTTT (-29) & CAATCGACCGAACGCGA $(-17)$ \\
\hline LINE-1-M1 & GGACGTATTTGGAAAATCGGG $(-21)$ & AATCTCGCGATACGCCGTT $(-19)$ \\
\hline SAT- $\alpha-\mathrm{M} 1$ & TGATGGAGTATTTTTAAAATATACGTTTTGTAGT $(-34)$ & ААТТСТАААААТАТТССТСТТСААТТАСGTААА (-33) \\
\hline
\end{tabular}

The results of each CT were obtained from each qMSP. Data were normalised with the housekeeping Alu C4 using the Nikolaidis et al. [38] and Liloglou et al. [39] comparative CT method $(\Delta \Delta \mathrm{CT})$. The differences between the tested compounds, repetitive elements and concentrations were evaluated applying one-way ANOVA and post-hoc Tukey's test.

\section{Results}

\subsection{Toxicity/Antitoxicity}

Toxicity assays showed that whereas ACK is significantly toxic at the highest concentrations, ASP and CYC are not toxic to D. melanogaster larvae (Table 2, simple treatment). However, the toxicity triggered by ACK is not enough to reach the classical lethal doses 50 $\left(\mathrm{LD}_{50}\right)$.

Table 2. Toxicity and antitoxicity levels of ASP, ACK and CYC in D. melanogaster.

\begin{tabular}{|c|c|c|c|c|c|c|c|c|}
\hline \multirow[t]{3}{*}{$\begin{array}{l}\text { ACK } \\
(\mathrm{mM})\end{array}$} & \multicolumn{2}{|c|}{$\begin{array}{c}\text { Survival } \\
(\%)\end{array}$} & \multirow[t]{2}{*}{$\begin{array}{c}\text { ASP } \\
(\mathrm{mM})\end{array}$} & \multicolumn{2}{|c|}{$\begin{array}{c}\text { Survival } \\
(\%)\end{array}$} & \multirow[t]{2}{*}{$\begin{array}{c}\text { CYC } \\
(\mathrm{mM})\end{array}$} & \multicolumn{2}{|c|}{$\begin{array}{c}\text { Survival } \\
(\%)\end{array}$} \\
\hline & Simple & Combined & & Simple & Combined & & Simple & Combined \\
\hline & Treatment $^{1}$ & Treatment $^{2}$ & & Treatment & Treatment & & Treatment & Treatment \\
\hline 0 & 100 & 100 & 0 & 100 & 100 & 0 & 100 & 100 \\
\hline $\mathrm{H}_{2} \mathrm{O}_{2}$ & - & 53.00 & $\mathrm{H}_{2} \mathrm{O}_{2}$ & - & 40.32 & $\mathrm{H}_{2} \mathrm{O}_{2}$ & - & 52.30 \\
\hline 0.006 & 89.32 & 50.68 & 0.0063 & 100.00 & $91.98 * 4$ & 0.0125 & 99.00 & 46.65 \\
\hline 0.025 & 91.00 & 53.00 & 0.025 & 100.00 & $88.65 *$ & 0.050 & 95.65 & $94.00 *$ \\
\hline 0.05 & $87.00 *, 3$ & 53.00 & 0.050 & 100.00 & $82.32 *$ & 0.100 & 98.00 & $84.67 *$ \\
\hline 0.2 & 86.36 * & 54.00 & 0.200 & 93.68 & $75.68^{*}$ & 0.400 & 99.00 & 51.64 \\
\hline 0.8 & $85.68 *$ & 57.00 & 0.815 & 95.97 & $64.35 *$ & 1.600 & 98.30 & 59.35 \\
\hline
\end{tabular}

${ }^{1}$ Data are expressed as a percentage of survival adults with respect to 300 untreated $72 \mathrm{~h}$-old larvae from three independent experiments. ${ }^{2}$ Combined treatments using standard medium and $0.15 \mathrm{M}$ hydrogen peroxide. ${ }^{3}$ Asterisks $\left(^{*}\right)$ indicate significant differences (one tail) with respect to the hydrogen peroxide control group and ${ }^{4}$ untreated control group: ${ }^{*}$ Chi-square value higher than 5.02 [40].

Antitoxicity results showed that ACK is not able to induce a significant protective effect against $\mathrm{H}_{2} \mathrm{O}_{2}$-induced toxicity in Drosophila larvae (Table 2, combined treatment). On the other hand, ASP and CYC were able to revert to some extent the damage caused by hydrogen peroxide in a negative dose-dependent and Gaussian-like manner, respectively. 


\subsection{Genotoxicity/Antigenotoxicity}

Table 3 shows the genotoxicity and antigenotoxicity results performing the SMART trial. The positive result of flies fed with hydrogen peroxide as a genotoxic control after applying the binomial Kastenbaum-Bowman test validated the accuracy of the SMART test. ASP, ACK and CYC yielded inconclusive results, which were resolved using MannWhitney U-test. This statistical test showed that none of the mentioned compounds was genotoxic at the assayed concentrations.

Table 3. Genotoxicity and antigenotoxicity of ASP, ACK and CYC in Drosophila wing spot test.

\begin{tabular}{|c|c|c|c|c|c|c|c|}
\hline \multicolumn{8}{|c|}{ Clones per Wings (Number of Spots) ${ }^{1}$} \\
\hline Compound & $\begin{array}{l}\text { Wings } \\
\text { Number }\end{array}$ & $\begin{array}{c}\text { Small Single Spots } \\
(1-2 \text { Cells) } \\
\mathrm{m}=2\end{array}$ & $\begin{array}{c}\text { Large Simple Spots } \\
\begin{array}{c}(>2 \text { Cells }) \\
\mathrm{m}=5\end{array}\end{array}$ & $\begin{array}{c}\text { Twin Spots } \\
\mathrm{m}=5\end{array}$ & $\begin{array}{c}\text { Total Spots } \\
\mathbf{m}=2\end{array}$ & $\begin{array}{c}\text { Mann-Whitney } \\
\text { Test }^{2}\end{array}$ & IP $(\%)^{3}$ \\
\hline $\mathrm{H}_{2} \mathrm{O}$ & 41 & $0.147(6)$ & $0.048(2)$ & 0 & $0.195(8)$ & & \\
\hline $\mathrm{H}_{2} \mathrm{O}_{2}(0.15 \mathrm{M})$ & 40 & $0.375(15)$ & $0.050(2)$ & 0 & $0.425(17)+$ & & \\
\hline \multicolumn{8}{|c|}{ Simple Treatment } \\
\hline \multicolumn{8}{|l|}{$\mathrm{ACK}(\mathrm{mM})$} \\
\hline [0.025] & 39 & $0.231(9)$ & 0.000 & 0 & $0.231(9) \mathrm{i}$ & $\lambda$ & \\
\hline$[0.8]$ & 40 & $0.200(8)$ & $0.025(1)$ & 0 & $0.225(9) \mathrm{i}$ & $\lambda$ & \\
\hline \multicolumn{8}{|l|}{$\mathrm{ASP}(\mathrm{mM})$} \\
\hline$[0.025]$ & 40 & $0.250(10)$ & $0.100(4)$ & 0 & $0.350(14) \mathrm{i}$ & $\lambda$ & \\
\hline$[0.82]$ & 40 & $0.200(8)$ & $0.075(3)$ & 0 & $0.275(11) \mathrm{i}$ & $\lambda$ & \\
\hline \multicolumn{8}{|l|}{ CYC (mM) } \\
\hline$[0.05]$ & 40 & $0.250(10)$ & 0 & $0.350(14) \mathrm{i}$ & $\lambda$ & & \\
\hline$[0.16]$ & 40 & $0.175(7)$ & 0.000 & 0 & $0.175(7) \mathrm{i}$ & $\lambda$ & \\
\hline \multicolumn{8}{|c|}{ Combined Treatment $\left(m w h / f l r^{3}\right)$} \\
\hline \multicolumn{8}{|l|}{ ACK (mM) } \\
\hline [0.025] & 40 & $0.200(8) \mathrm{i}$ & $0.050(2) \mathrm{i}$ & $0-$ & $0.250(10) \Delta$ & & 41 \\
\hline$[0.8]$ & 40 & $0.275(11) \mathrm{i}$ & $0.000-$ & $0-$ & $0.275(11) \Delta$ & & 35 \\
\hline \multicolumn{8}{|l|}{$\mathrm{ASP}(\mathrm{mM})$} \\
\hline$[0.025]$ & 38 & $0.130(5)$ & $0.050(2)$ & 0 & $0.184(7) \Delta$ & & 57 \\
\hline [0.82] & 40 & $0.250(10)$ & $0.125(5)$ & 0 & 0.375 (15) $\Delta$ & & 12 \\
\hline \multicolumn{8}{|l|}{ CYC (mM) } \\
\hline$[0.05]$ & 40 & $0.125(5)$ & $0.025(1)$ & 0 & $0.150(6) \Delta$ & & 65 \\
\hline$[0.16]$ & 39 & $0.175(7)$ & $0.026(1)$ & 0 & $0.205(8) \Delta$ & & 52 \\
\hline
\end{tabular}

${ }^{1}$ Statistical diagnosis according to Frei and Wurgler (1988) [41]: + (positive), - (negative) and i (inconclusive) vs negative control; ${ }^{*}$ (positive), $\Delta$ (negative) and $\beta$ (inconclusive) vs. respective positive control; m: multiplication factor. Kastenbaum-Bowman Test without Bonferroni correction, probability levels: $\alpha=\beta=0.05$. No. of spots in parentheses. ${ }^{2}$ Mann-Whitney test was used when appropriate to resolve inconclusive results. Lambda symbol $(\lambda)$ means that there are not significant differences with respect to the negative control. ${ }^{3}$ Inhibition percentage values were included when appropriate.

On the other hand, all assayed substances significantly exerted an antigenotoxic activity being each combined mutation rate below the genotoxin alone ( 0.425 clones / wings). All tested compounds showed a negative dose-dependent protective effect against the genotoxin. CYC was the highest antigenotoxic compound yielding an Inhibition Percentage (IP) of 52\% and $60 \%$ for the lowest and the highest concentration, respectively. The IP value obtained in ACK treatments was quite similar, roughly $30 \%$ and $40 \%$. ASP was able to inhibit the effect of the genotoxin, yielding $57 \%$ and $12 \%$ IP values for the lowest and the highest concentrations, respectively.

\subsection{Lifespan}

Estimated mean values of Drosophila's survival were obtained using the Kaplan-Meier curves (Figure 1), and statistical differences were determined by the Log-Rank (MantelCox) test. ASP (0.05 mM and $0.2 \mathrm{mM})$ was able to induce an increase in longevity $(8 \%)$. However, neither ACK nor CYC exerted any effect on Drosophila's lifespan since they were statistically similar to their concurrent control. 

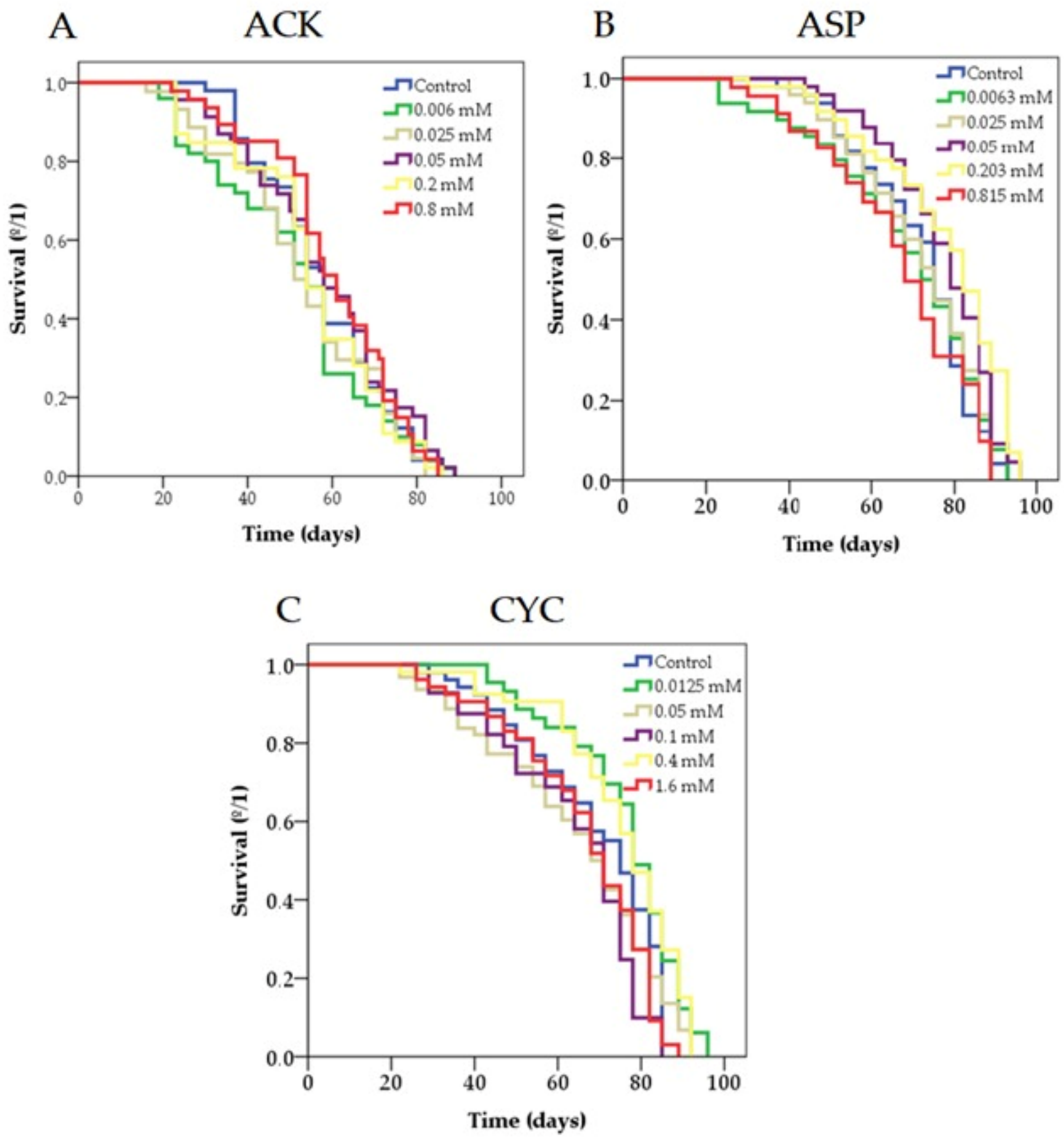

Figure 1. Effect of ASP (A), ACK (B) and CYC (C) supplementation on the lifespan of Drosophila melanogaster.

Healthspan parameters were performed, taking into account the portion $\geq 80 \%$ of lifespan curves (Table 4). The results showed that when statistical differences were found, it is to decrease the quality of life in this in vivo experimental model as follows: $0.025 \mathrm{mM}$ and $0.2 \mathrm{mM}$ ACEK decreasing it roughly $28 \%$, the highest and the lowest tested concentration of ASP reduced the healthspan approximately $30 \%$ and $0.05 \mathrm{mM} \mathrm{CYC} \mathrm{(27 \% )} \mathrm{also} \mathrm{decreased}$ the quality of life. 
Table 4. Effects of ACK, ASP and CYC treatments on the Drosophila melanogaster mean lifespan and healthspan.

\begin{tabular}{|c|c|c|c|c|}
\hline $\begin{array}{c}\text { Compound } \\
\text { (Concentration) }\end{array}$ & Mean Lifespan (Days) & $\begin{array}{l}\text { Mean Lifespan } \\
\text { Difference (\%) }\end{array}$ & $\begin{array}{l}\text { Healthspan (80th } \\
\text { Percentile) (Days) }\end{array}$ & $\begin{array}{c}\text { Healthspan } \\
\text { Difference (\%) }\end{array}$ \\
\hline \multicolumn{5}{|l|}{$\mathrm{ACK}(\mathrm{mM})$} \\
\hline Control & $57.630 \pm 2.108$ & 0 & $38.630 \pm 1.600$ & 0.00 \\
\hline 0.006 & $51.360 \pm 2.720$ & -10.87 & $40.600 \pm 3.560$ & 5.10 \\
\hline 0.025 & $53.182 \pm 2.707$ & -7.70 & $27.50 \pm 2.100 * *$ & -28.80 \\
\hline 0.05 & $58.022 \pm 2.635$ & 0.70 & $43.830 \pm 5.000$ & 13.46 \\
\hline 0.2 & $54.783 \pm 2.560$ & -4.94 & $28.100 \pm 2.210^{* *}$ & -27.25 \\
\hline 0.8 & $59.702 \pm 2.300$ & 3.60 & $23.200 \pm 0.990^{* * *}$ & -40.00 \\
\hline \multicolumn{5}{|c|}{$\mathrm{ASP}(\mathrm{mM})$} \\
\hline Control & $71.830 \pm 1.980$ & 0.00 & $52.524 \pm 2.000$ & 0.00 \\
\hline 0.0063 & $68.520 \pm 2.950$ & -4.60 & $38.150 \pm 3.640 * *$ & -27.36 \\
\hline 0.025 & $71.636 \pm 2.300$ & -0.27 & $48.540 \pm 1.540$ & -7.57 \\
\hline 0.05 & $77.193 \pm 200 *$ & 7.46 & $56.080 \pm 2.040$ & 6.77 \\
\hline 0.2 & $77.720 \pm 2.400 * *$ & 8.20 & $49.300 \pm 3.000$ & -6.13 \\
\hline 0.815 & $67.135 \pm 2.680$ & -6.54 & $36.450 \pm 2.970 *$ & -30.60 \\
\hline \multicolumn{5}{|l|}{ CYC (mM) } \\
\hline Control & $69.200 \pm 2.350$ & 0.00 & $40.889 \pm 2.210$ & 0.00 \\
\hline 0.0125 & $76.460 \pm 2.260$ & 10.50 & $44.300 \pm 1.300$ & 8.34 \\
\hline 0.05 & $64.720 \pm 2.640$ & -6.47 & $29.850 \pm 1.720 * *$ & -27.00 \\
\hline 0.1 & $63.970 \pm 2.900$ & -7.56 & $34.170 \pm 2.265$ & -16.43 \\
\hline 0.4 & $75.387 \pm 2.212$ & 8.94 & $51.000 \pm 4.000$ & 24.72 \\
\hline 1.6 & $66.550 \pm 2.340$ & -3.83 & $41.700 \pm 2.900$ & 1.98 \\
\hline
\end{tabular}

\subsection{Cytotoxicity}

Figure 2 shows the cytotoxicity results obtained in the HL-60 cells treatments with the different compounds during $72 \mathrm{~h}$. ACK was the most cytotoxic compound reaching the Inhibitory Concentration $50\left(\mathrm{IC}_{50}\right)$ at $0.08 \mathrm{mM}$. ASP also reached the $\mathrm{IC}_{50}$ at $0.8 \mathrm{mM}$, the highest concentration used in this assay. Despite the fact that CYC decreased the cell viability of the HL-60 cell line at the lowest concentration, the $\mathrm{IC}_{50}$ was not reached, and the cell viability was maintained at around $70 \%$.

\subsection{DNA Fragmentation}

The typical internucleosomal DNA ladder pattern in apoptotic cells was not observed in any treatment with the tested compounds (Figure 3).

\subsection{Comet Assay}

Figure 4 shows the ability of the tested compounds to exert DNA damage due to single and double-strand breaks in the HL-60 cell line since an alkaline comet assay was conducted. The concentrations used in this SCGE assay were determined according to the results obtained in the previous cytotoxicity assay. The results showed that ASP significantly induced DNA damage at the highest tested concentration. Moreover, CYC was able to induce DNA strand breaks at all the assayed concentrations. On the contrary, ACK did not significantly increase the TM parameter at any concentration compared to the concurrent control, except for the lowest concentration. 

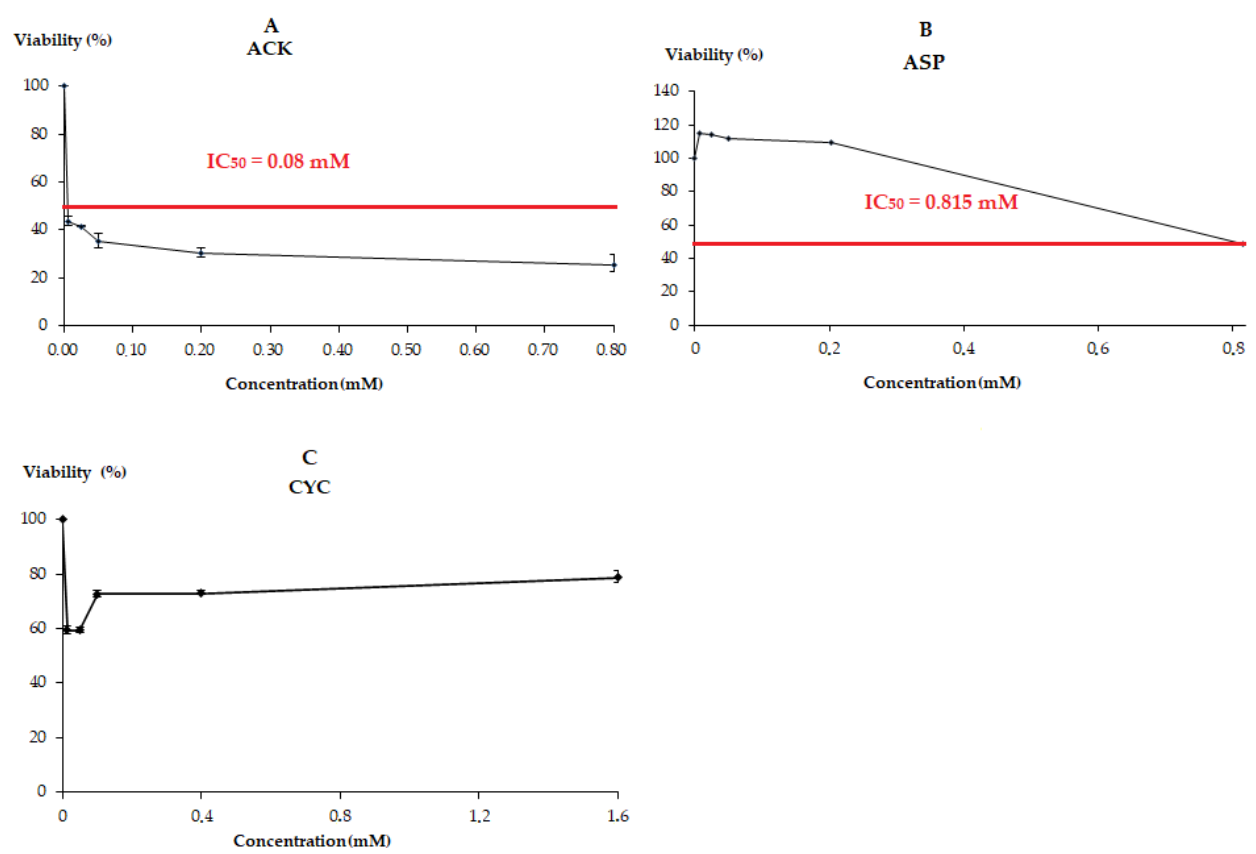

Figure 2. Cytotoxic effects of ACK (A), ASP (B) and CYC (C). Viability curves at $72 \mathrm{~h}$ of treatment.

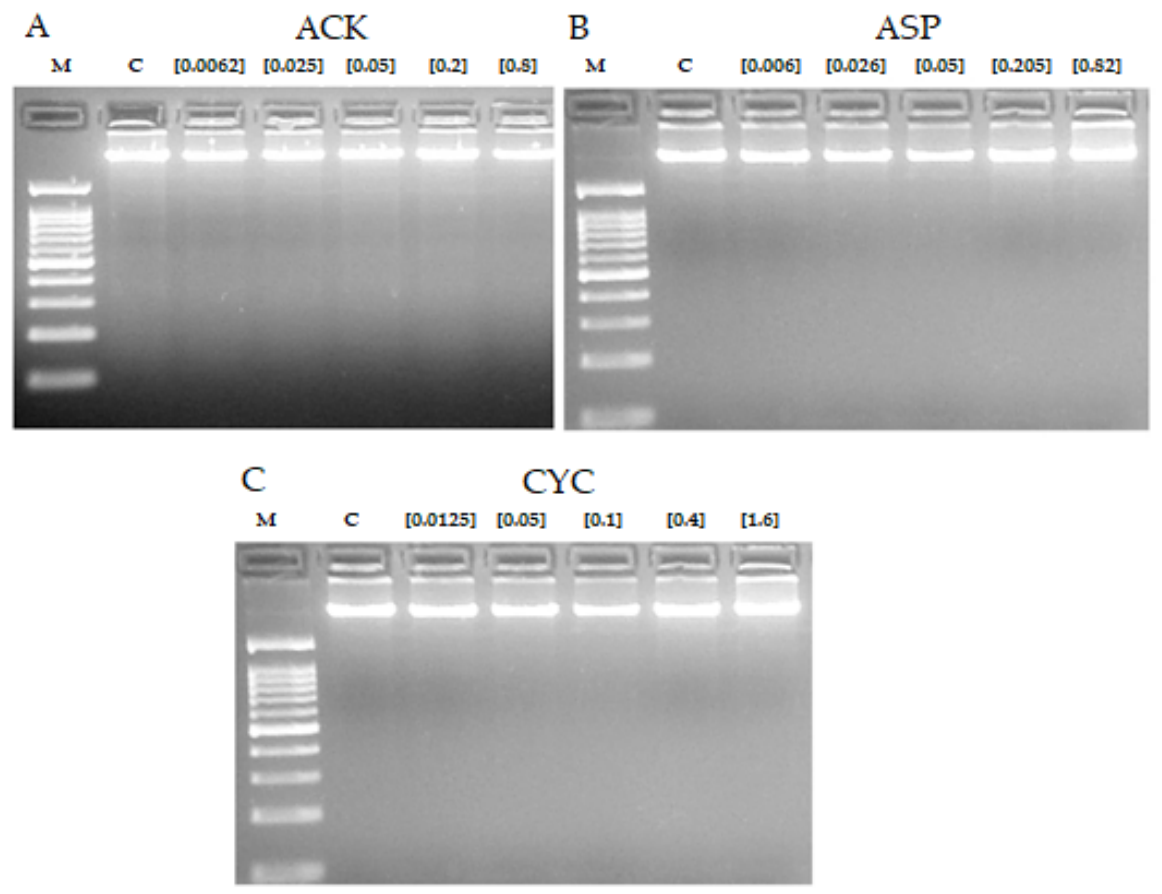

Figure 3. Internucleosomal DNA fragmentation after $5 \mathrm{~h}$ of treatment with ACK (A), ASP (B) and CYC (C). Letters $M$ and C mean weight size marker and negative control, respectively.

\subsection{Methylation Status}

Figure 5 shows the relative normalised methylation status (RMS) of the three repetitive sequences (LINE-1, Alu M1, and Sat- $\alpha$ ) in the HL-60 cell line treated with the tested compounds. ACK was able to induce hypermethylation in the three repetitive sequences analysed. Regarding ASP, the lowest concentration studied in this assay significantly hypomethylated Sat $\alpha$ and hypermethylated Alu M1 sequence. As regards CYC, this artificial sweetener showed a similar pattern to ASP modifying Satellite and Alu sequences. In this case, CYC was able to reduce the methylation status in Alu M1 and Sat- $\alpha$ repetitive 
elements when cells are treated with both assayed concentrations and the lowest one, respectively. It is noteworthy the lack of dose-dependent response as it is shown in Figure 5.
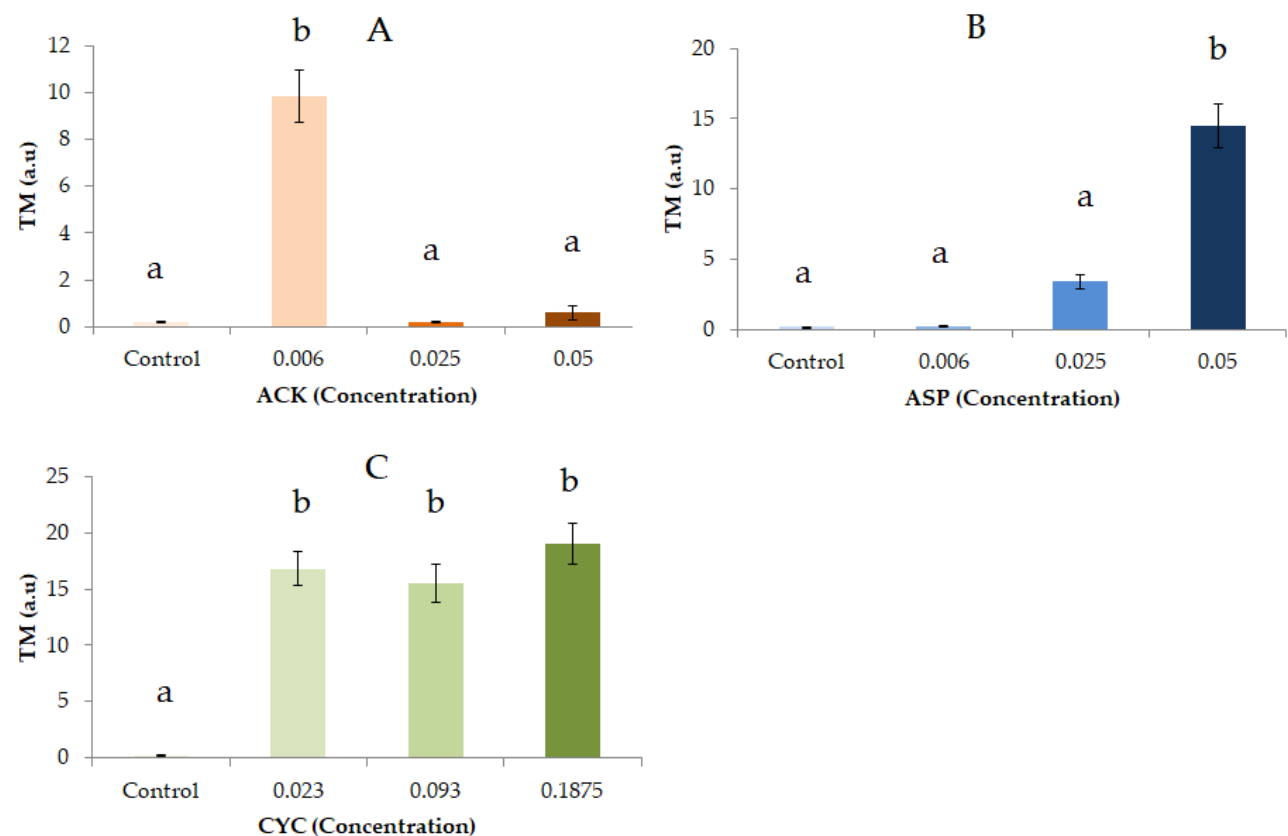

Figure 4. Alkaline comet assay $(\mathrm{pH}<13)$ of HL-60 cells after 5 h-treatment with different concentrations of ACK (A), ASP (B) and CYC (C). DNA migration is reported as mean TM. The plot shows mean TM values and standard errors. Different letters mean different values after one-way ANOVA and post hoc Tukey's test.
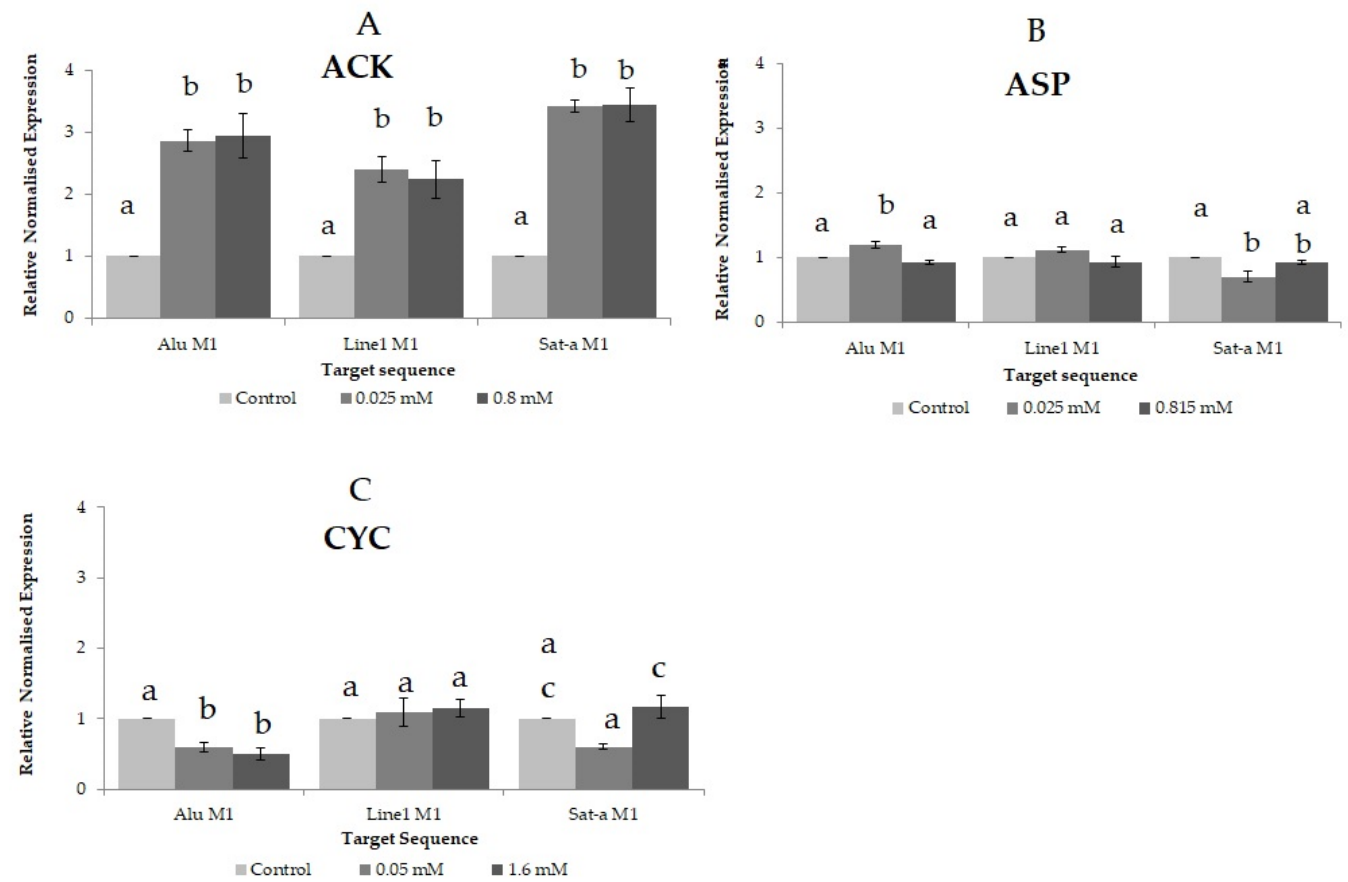

Figure 5. Relative normalised expression data of each repetitive element when HL-60 cell line was treated with ACK (A), ASP (B) and CYC (C). Different letters are associated with different means applying the One-Way ANOVA test and post hoc Tuckey's test. 


\section{Discussion}

Artificial sweeteners are food additives worldwide used as sugar substitutes in beverages, being sweeter than sugar and with fewer calories content [1,2]. As their consumption has been increasing every year, some food agencies (FDA and EFSA) are responsible for regulating their safe intake. Despite there being many studies determining their carcinogenicity and toxicity, food agencies do not support that relationship. Debates and controversial results were raised, and authorities should revise their decision on the basis of new data reporting toxicological effects [6,7].

ASP, CYC and ACK are used instead of FRU and GLU as sweeteners without providing energy in diet cola beverages. Besides the controversial information about artificial sweeteners, CYC has been forbidden in many countries [8].

Artificial sweeteners were evaluated in the last century to ascertain their ADI to be added to FDA as safety compounds. This is the reason why the main information available on the database is dated from the 1970s to the 1990s. However, controversial information has been found, and it is necessary to carry out new scientific data which assure their safety for human health [42]. We performed toxicity, antitoxicity, genotoxicity, antigenotoxicity and lifespan assays to assess the nutraceutical potential and safety of three artificial sweeteners. It used the concentrations of ACK, ASP, and CYC declared by the Coca-Cola Company.

In vivo model

Our toxicity results showed that none of the artificial sweeteners was toxic since $\mathrm{LD}_{50}$ was not reached at the assayed concentrations, although the three highest concentrations significantly differed from the concurrent control. These results agree with the safety demonstrated by ACK by Jung and Kreiling [43]. Mukherjee and Chakrabarti [44] reported ACK not to be toxic in mice fed with $1.5-3 \mathrm{~g} / \mathrm{kg}$ of body weight, and Mayer [45] determined that ACK was accepted for human consumption since it was not toxic. Our results are also consistent with those obtained by Reuzel and van der Heijden [46], who reported that ACK was revealed as a non-toxic compound in the diet of dogs fed with $900 \mathrm{mg} / \mathrm{kg}$ body weight/day. Our results are also supported by acute toxicology tests performed in rats, mice and rabbits with a maximum dose of $5000 \mathrm{mg} / \mathrm{kg}$ body weight with negative results [47]. The lack of toxicity of ACK could be due to the fact that this sweetener is not metabolised and is excreted without any modification [48]. Bandyopadhyay et al. [49] found that although ACK and ASP were not toxic in the Ames Test, their lack of toxicity is still controversial and confusing in spite of the Ames test being conducted in a prokaryotic organism; hence this result is not determining enough. ASP was reported to have low toxicity in experimental model systems. In pregnant rats, ASP proved to be nephrotoxic in the fetus at $14 \mathrm{mg} / \mathrm{kg}$ body weight [50]. ASP was toxic in Wistar rats at $0.83 \mathrm{mM}$ since the enzymatic activity was reduced, generating neurologic diseases [51]. In addition, ASP had an influence on neurologic behaviour in humans at 10 and $20 \mathrm{mg} / \mathrm{kg}$ suffering from headaches [52]. However, ASP (from 20 to $320 \mathrm{mM}$ ) did not exert toxicity in the third instar larvae of D. melanogaster, which is fit with our results [53]. Therefore, ASP remains one of the most controversial and widely used artificial sweeteners today [54] and the toxicity of ASP has been demonstrated that depends on the concentration used in the assays according to Weerasooriyagedara [55] reported in Danio rerio.

Our results are consistent with toxicological studies of CYC mainly performed during the 1970s and 1980s since CYC was determined as a non-toxic sweetener in mice [56,57]. In addition, CYC was demonstrated not to be toxic in human studies [58] and in Drosophila Sex-linked recessive lethal assay [59]. On the other hand, CYC showed very low toxicity, although it is metabolised to cyclohexylamine, which shows higher toxicity [60]. Moreover, CYC was toxic to some extent in pregnant rats since $60 \mathrm{mg} / \mathrm{kg}$ of body weight of CYC led to retardation of fetal development and hypertrophy in the exocrine pancreas of the rat fetuses [61]. In addition, CYC $(0.06 \mu \mathrm{M})$ was demonstrated to be toxic in osteoblasts inhibiting their proliferation and differentiation [62], and it may be due to the fact that a specific interaction between CYC and adenine and guanine exists [63]. 
Therefore, we hypothesise that the toxicity or the lack of it depends on the tested concentrations and the model organism used in the assays performed.

Drosophila has been extensively used as an experimental model evaluation of the genotoxicity exerted by different compounds in many tests. The main information available on the scientific database about artificial sweeteners is related to genotoxicity and carcinogenicity assays. Our results revealed that all the tested compounds were not genotoxic at the assayed concentrations.

ACK was reported to be non-mutagenic in E. coli and mammalian cells [64,65]. In addition, several studies carried out during the 1970s and 1980s determined that ACK was neither mutagenic nor carcinogenic in in vivo and in vitro assays. Despite ACK being clastogenic and genotoxic at higher doses $(60-2250 \mathrm{mg} / \mathrm{kg})$ on mice, these concentrations were not within the ADI dose. In this sense, although the number of chromosomal aberrations induced by ACEK ( $15 \mathrm{mg} / \mathrm{kg})$ was similar to the control, ACK was demonstrated to interact with DNA inducing genetic damage [44]. ACK and ASP were not mutagenic to S. typhimurium in the Ames Mutagenicity test. The majority of studies performed during the 1970s and 1980s supporting the safety of ASP had no statistical analysis [49]. The reports on the ASP genotoxicity are incongruent since it exerted a genotoxic effect in human lymphocytes using micronucleus test but had no mutagenic effect conducting the Ames Salmonella test with microsomal activation [66]. Soffritti et al. [67] provided evidence of the carcinogenic potential of ASP increasing the malignant tumours in Sprague-Dawley fetal rats using the ADI for humans. Chromosome aberrations and sister chromatid exchanges tests were performed in mice fed with ASP, resulting from being non-genotoxic at low concentration $(3.5 \mathrm{mg} / \mathrm{kg})$, but it was concluded that ASP has a genotoxic risk [68]. Furthermore, our results do not fit with those obtained by Elfatah et al. [69] and Kashanian et al. [70], who concluded that ASP was genotoxic inducing chromosomal aberration in albino rats and DNA bindings in calf thymus DNA, respectively. Soffritti et al. [71] and Schernhammer et al. [72] revealed that ASP could cause some kinds of tumours in Sprague rats and humans respectively. Another assay carried out in this decade revealed $455 \mathrm{mg} / \mathrm{kg}$ ASP to be clastogenic in bone marrow and peripheral blood micronucleus [73]. Our results are in agreement with those obtained by Demir et al. [74], who performed SMART in Drosophila and concluded that whereas ACK was not genotoxic, ASP did induce positive results, although at higher concentrations than we used in this assay. Mohammed [75] also conducted genotoxicity assays in Drosophila, concluding that ASP was not genotoxic at $0.75 \mathrm{mM}$. Thus, our results are congruent with those. The genotoxic risk of ASP may be associated with its metabolites (aspartic acid, phenylalanine and methanol) which showed genotoxic potential [76].

On the other hand, CYC had no genotoxicity in Drosophila and in rat hepatocytes [59]. CYC was reported as a non-genotoxic compound, and there is evidence to indicate a slight possibility that CYC or some of its metabolites was a DNA-reactive carcinogen [77]. In addition, a lack of DNA damage in Sprague rats induced by CYC was reported by Jeffrey and Williams [78]. Taking into account all this information, further genotoxicity and carcinogenicity studies should be conducted to reach a clear view on its safety [74,79]; hence our results provide some necessary data to the scientific community.

A compound that is able to protect DNA against oxidative damage could be considered as a nutraceutical substance, and antioxidants properties would be shown by this compound. We carried out antitoxicity and antigenotoxicity assays in order to evaluate the capability of our tested compounds. Our results showed that low concentrations of ASP and CYC statistically behaved as antioxidants compounds against hydrogen peroxide on Drosophila larvae. Contrarily, ACK was not able to protect the individuals against this genotoxine. On the other hand, the antigenotoxicity assay showed that all tested compounds were able to revert to greater or less extent the oxidative damage caused by hydrogen peroxide on Drosophila's DNA.

Antioxidant compounds act, providing cells with mechanisms to defend themselves from ROS-induced damage. Glutathione, ascorbate, superoxide dismutase, catalase and 
glutathione-dependent antioxidant enzymes are compounds that exert antioxidant defence [80]. It is demonstrated that after 15 days of ASP consumption $(40 \mathrm{mg} / \mathrm{kg} \mathrm{b.w})$, rats exerted an increase in superoxide dismutase, glutathione peroxidase and catalase and a reduction of glutathione which means an increase of antioxidant level from free radical production. However, when time exposure to ASP was increased, the free radical production over helmed the antioxidant defence producing a decrease in antioxidant molecules. Therefore, ASP provokes a dose dependent oxidant/antioxidant imbalance in rats [81]. In addition, ASP was found to be antigenotoxic, reverting the damage caused by the mycotoxin ochratoxin A feeding rats with $25 \mathrm{mg} / \mathrm{kg}$ [82]. Conversely, Abhilash et al. [83] concluded that ASP was able to modify the antioxidant defence status of rats fed with $1000 \mathrm{mg} / \mathrm{kg}$ ASP and be responsible for oxidative stress [84,85].

With this regard, ACK also produced oxidative stress in Cyprinus carpio, modifying the activity of superoxide dismutase and catalase [86], and the pancreas of diabetic rats showed an improvement in antioxidant conditions when this model organism was fed with CYC and saccharin producing glutathione reductase and superoxide dismutase [87].

With this in mind, we hypothesise that the activation of the antioxidant mechanisms depends on the dose of administration, showing a dose-dependent influence and also depends on the model organism which it is used. Therefore, when cells are treated at low concentrations, the antioxidant mechanisms are increased, but the oxidant/antioxidant imbalance occurs when the concentration exceeds the threshold allowed by the kind of cell and the model organism and then, the ROS production is higher than the antioxidant activity.

To our knowledge, there is no information evaluating the antigenotoxic effects of ACK and CYC.

Drosophila melanogaster is an excellent experimental model for assessing lifespan extension and ageing since the cellular senescence observed in mammals is similar to those observed in Drosophila [88]. Based on our results, we concluded that ASP increased the lifespan of Drosophila and decreased the quality of life of this fly as well as ACK and CYC. Our results do not fit with previous reports about a decrease in life expectancy induced by ASP at 0.06-1 mM in Drosophila [89]. Soffritti et al. [90] determined that ASP decreases the longevity of Sprague-Dawley rats at $6.8-108.8 \mathrm{mM}$. In addition, our results are not congruent with those obtained by Huang [91], who declared that $1 \%$ ASP reduced the longevity of Drosophila after a period of time in which the quality of life would not be affected. Overall, our results are consistent with the assumption that the caloric restriction on Drosophila is not responsible for an increase in the lifespan [92]. In addition, our results are fit with those obtained by Anbara et al. [93], who reported that long-term consumption of ASP induced oxidative stress in male mice provoking reproductive damages, which could reduce the quality of life.

To our knowledge, this is the first attempt evaluating the CYC based on the current longevity assay since previous reports dating from the 1970s to the 1980s where CYC increased the lifespan of rats fed with $0.43 / 100 \mathrm{~g}$, although the differences were not analysed statistically [94].

In vitro trials

The in vitro studies of mechanisms against cancer are needed to be extrapolated to human therapies, which are still unknown in the scientific field. We herein determined the cytotoxic activity of three artificial sweeteners (ACK, ASP and CYC) in order to evaluate their chemopreventive potential against promyelocytic leukaemia cells (HL-60 cell line). Internucleosomal DNA fragmentation assay was performed to elucidate if the death cell studied in the cytotoxicity assay was caused by proapoptotic mechanisms. In addition, a comet assay was carried out to assess the clastogenic potential of these compounds, inducing genetic damage in single and double DNA strands. Moreover, the HL-60 cell line was also treated with the tested substances and undergone qMSP to evaluate the potential of these compounds to globally modify the epigenome using three repetitive elements: 
ALUM1, LINE- 1 and SAT- $\alpha$. The main aim is to characterise the nutraceutical potential of the tested compounds.

Our cytotoxicity assay showed that all tested compounds were able to reach the $\mathrm{IC}_{50}$, except for CYC. Although ACK was cytotoxic, it seems to be non-specific against tumoural cells since ACK can damage the DNA of normal cells such as human lymphocytes at 0.006 and $0.02 \mathrm{mM}$ [95]. Our results are not in agreement with those obtained by Pandurangan et al. [96], who demonstrated that ASP was not able to decrease the cell viability significantly in HeLa cells exposed to $0.01-0.05 \mathrm{mg} / \mathrm{mL}$ ASP. Oyama et al. [97] reported that ASP at abuse doses could be harmless to humans since 1-3 mM formaldehyde (a derived from ASP) may cause cytotoxicity in rat thymocytes. Therefore, there is evidence to state that the effect of ASP could be due to its derived metabolites. Regarding CYC, it was tested using The Weaver Human Cell Test and interpreted as an artificial sweetener marginally cytotoxic decreasing $20 \%$ de cell viability [98] which is in agreement with our result to some extent. Conversely, evidence about the cytotoxic effect of $1 \mathrm{mg} / \mathrm{mL}$ CYC was found in rat hepatocytes by Brusick, Cifone, Young and Benson [55].

As far as genetic damage is concerned, it is well-known that internucleosomal DNA fragmentation is one of the main processes which occur in apoptotic cells. On the other hand, an alkaline SCGE (comet assay) trial was conducted in order to detect DNA damage in single and double strands [99], which could be considered as early treatment of acute promyelocytic leukaemia [100]. Necrosis or apoptosis mechanisms can be detected throughout comet assay using the TM parameter to quantify the genetic damage [101]. Our results revealed that none of the tested compounds was able to induce DNA fragmentation since the typical apoptotic ladder pattern was not found. However, the assayed substances provided DNA strand breaks to greater or less extent conducting SCGE assay. It is known that DNA damage can be divided into five classes according to the TM values [102]. CYC and $0.05 \mathrm{mM}$ ASP fell into class 3 (TM 10-20), which means that CYC induces serious damage in the HL-60 cell line. A cell is considered not damaged when the TM value is between 0 and 1 (class 0 ). The concurrent control of each artificial sweetener exerted a TM value lower than 1 . Therefore, all concurrent control values demonstrated the accuracy of the comet assay. Finally, the results of DNA fragmentation fit with those obtained in the comet assay since TM values higher than 30 were not found, which would mean that apoptosis mechanisms are not being induced by any tested compound [103]. Necrosis is hence the main cell death mechanism triggered by our compounds.

Clastogenic activity of ASP has extensively been measured in liver, and bone marrow cells of rats [47,69], reporting controversial results since Butchko, et al. [47] reviewed a lack of clastogenicity. In contrast, Ghaly, and Hanafy [69] demonstrated that ASP is able to induce DNA fragmentation and chromosomal aberrations in rats bone marrow cells. Lack of genotoxicity was also found by Jeffrey and Williams [78] in rat hepatocytes for the three sweeteners tested in this study. Related to this absence of DNA damage, ASP has been reported as a potent substance to slow down the apoptosis process in HeLa cells, supporting our results, and more information is needed to understand the behaviour of ASP in cancer cells [96]. Contrarily, $100 \mathrm{mM}$ and $27 \mathrm{mM}$ ASP induced apoptosis in thymocytes [104] and PC12 Wistar rats cells [105], although this kind of cell is non-tumoural. No clastogenic activity was found in the tested compounds by Durnev et al. [106] in mice. CYC was found to produce chromosome breakage in mammalian systems in vitro a long time ago [107]. Our results agree with Sasaki et al. [108], who revealed that CYC was able to increase the DNA damage, measuring the DNA migration in the comet assay, in the glandular stomach, colon, kidney and urinary bladder in mice. However, their results obtained in ACK and ASP are not fit with our findings since these both compounds were not able to induce any DNA damage. Moreover, Demir, Turna, Aksakal, Kaya, and Marcos [74] determined that ACEK did not damage the DNA of normal cells in Drosophila performing the comet assay. Van Eyk [109] reported that $10 \mathrm{mM}$ ACK is able to fragment the DNA of both normal and tumoural cells in the mouse. Our results are supported up to a point by the assumption that ACK and ASP increased the comet-tail extent and per cent DNA in the tail in rat bone 
marrow also conducting the comet assay [49]. ASP induced apoptosis at 35 and $3.5 \mathrm{mg} / \mathrm{kg}$ and necrosis at 35 and $350 \mathrm{mg} / \mathrm{kg}$ in albino mice from peripheral blood cells [110].

By taking into account both the DNA fragmentation and the comet assay results, the tested sweeteners may induce a necrotic-mediated chemopreventive activity. This potential chemopreventive result is supported by Murray et al. [111], who established the potential of artificial sweeteners (ACK and saccharine) as a specific inhibitor compound of carbonic anhydrase IX isoforms, which is upregulated in cancer cells and is used in anticancer chemotherapy.

It is known that the transposable elements are hypomethylated in cancer cells triggering genomic instability [112]. Besides this global hypomethylation, specific hypermethylation of tumour suppressor genes is also related to cancer cells [113]. Both global hypermethylation and specific hypomethylation are being performed in therapies against cancer. However, biomedical research is focused on hypomethylation agents that could activate tumour suppressor genes. More information is needed since their benefit on human health has not been totally demonstrated yet [114]. The methylation status of the HL-60 cell line was measured using three repetitive elements (Alu M1, LINE M1 and Sat- $\alpha$ ). Long interspersed nuclear elements (LINE) represent about $17 \%$ of the human genome, and they are accumulated in AT-rich regions of chromosomes, Alu (short interspersed nuclear elements-SINE) is present in noncoding and GC-rich regions, and Satellite alpha DNA (Sat- $\alpha$ ) are consisted in tandem repeats of $170 \mathrm{bp}$ mainly in centromere, and represent about $5 \%$ of total human DNA $[115,116]$. Therefore, the LINE and Alu regions are useful repetitive elements in order to evaluate the methylation status of the target DNA since $32 \%$ of the human genome is measured [117].

Our results showed that ACK significantly hypermethylated the three target sequences, and ASP was able to increase the methylation status of Alu at $0.025 \mathrm{mM}$ and hypomethylated Sat- $\alpha$ sequence at the same concentration. Conversely, CYC reduced the methylation levels in Alu and Sat- $\alpha$. The hypermethylation observed in LINE- 1 and Sat- $\alpha$ repetitive elements when cells are treated with ACK could be considered as a benefit since LINE-1 repetitive element has been related to C-met oncogene triggering its gene silencing [118], and it is known that a methylation process in satellite sequences could be a potential mechanism for silencing its expression in transformed cells since this repetitive sequence is hypomethylated in cancer cells [119]. The information about this methylation status assay is really scarce using these artificial sweeteners and mainly related to the methylation process, which they suffer from yielding other derived-compound. Therefore, much more research is needed using additive performing methylation assays [120].

\section{Conclusions}

In conclusion, all tested artificial sweeteners were safe compounds at assayed concentrations since toxicity and genotoxicity were not significantly induced in flies. Moreover, ASP and CYC showed protective activity against a genotoxin in Drosophila. On the other hand, the quality of life of the in vivo organism was reduced in ACK, ASP and CYC treatments. Regarding nutraceutical potential, ACK and ASP could be demonstrated to be chemopreventive due to the cytotoxicity activity shown by these compounds. According to DNA damage activity, as it was obtained in the SCGE assay, a necrotic way could be the main mechanism of death cell induced by ACK, ASP and CYC. In addition, ACK hypermethylated repetitive elements, which are hypomethylated in cancer cells resulting in a benefit to humans.

Author Contributions: Conceptualization, Á.A.-M. and M.D.R.C.; methodology, M.M.-F.; M.J.G.-J. and T.M.-A.; formal analysis, M.M.-F.; investigation, Á.A.-M.; M.D.R.C. and R.F.; writing-original draft preparation, M.M.-F. and M.J.G.-J.; writing—review and editing, Á.A.-M.; M.D.R.C. and T.M.-A. All authors have read and agreed to the published version of the manuscript.

Funding: No external funding was received. 
Data Availability Statement: The data presented in this study are available from the corresponding author on reasonable request.

Conflicts of Interest: The authors declare no conflict of interest.

\section{References}

1. Lange, F.T.; Scheurer, M.; Brauch, H.-J. Artificial sweeteners-A recently recognized class of emerging environmental contaminants: A review. Anal. Bioanal. Chem. 2012, 403, 2503-2518. [CrossRef] [PubMed]

2. Chung, Y.-S.; Lee, M. Genotoxicity assessment of erythritol by using short-term assay. Toxicol. Res. 2013, 29, 249. [CrossRef] [PubMed]

3. Yang, Q. Gain weight by “going diet?" Artificial sweeteners and the neurobiology of sugar cravings: Neuroscience. Yale J. Biol. Med. 2010, 83, 101-108.

4. Pang, M.D.; Goossens, G.H.; Blaak, E.E. The Impact of Artificial Sweeteners on Body Weight Control and Glucose Homeostasis. Front. Nutr. 2021, 7, 598340. [CrossRef] [PubMed]

5. García, A.; Martínez, J.A. Los edulcorantes y su papel sobre el metabolismo humano. Dialnetplus 2016, 4, 13-22.

6. Marinovich, M.; Galli, C.L.; Bosetti, C.; Gallus, S.; La Vecchia, C. Aspartame, low-calorie sweeteners and disease: Regulatory safety and epidemiological issues. Food Chem. Toxicol. 2013, 60, 109-115. [CrossRef]

7. Mishra, A.; Ahmed, K.; Froghi, S.; Dasgupta, P. Systematic review of the relationship between artificial sweetener consumption and cancer in humans: Analysis of 599,741 participants. Int. J. Clin. Pract. 2015, 69, 1418-1426. [CrossRef]

8. Cillo, F. 0\% Calorías, \% azúcares. Un análisis sobre las bebidas light del mercado. La tendencia a endulzar naturalmente: Stevia. ISDe Sports Mag. 2011, 3, 8.

9. Durán, S.; Cordón, K.; Rodríguez, M.D.P. Edulcorantes no nutritivos, riesgos, apetito y ganancia de peso. Rev. Chil. Nutr. 2013, 40, 309-314. [CrossRef]

10. Wu, G.D.; Chen, J.; Hoffmann, C.; Bittinger, K.; Chen, Y.-Y.; Keilbaugh, S.A.; Bewtra, M.; Knights, D.; Walters, W.A.; Knight, R.; et al. Linking Long-Term Dietary Patterns with Gut Microbial Enterotypes. Science 2011, 334, 105. [CrossRef]

11. Bian, X.; Chi, L.; Gao, B.; Tu, P.; Ru, H.; Lu, K. The artificial sweetener acesulfame potassium affects the gut microbiome and body weight gain in CD-1 mice. PLoS ONE 2017, 12, e0178426. [CrossRef]

12. Shanmugasundaram, K.; Nayak, B.K.; Friedrichs, W.E.; Kaushik, D.; Rodriguez, R.; Block, K. NOX 4 functions as a mitochondrial energetic sensor coupling cancer metabolic reprogramming to drug resistance. Nat. Commun. 2017, 8, 997. [CrossRef] [PubMed]

13. Ibi, D.; Suzuki, F.; Hiramatsu, M. Effect of AceK (acesulfame potassium) on brain function under dietary restriction in mice. Physiol. Behav. 2018, 188, 291-297. [CrossRef]

14. Merinas-Amo, T.; Lozano-Baena, M.-D.; Obregón-Cano, S.; Alonso-Moraga, Á.; de Haro-Bailón, A. Role of Glucosinolates in the Nutraceutical Potential of Selected Cultivars of Brassica rapa. Foods 2021, 10, 2720. [CrossRef]

15. Arnold, D.; Boyes, B. The toxicological effects of saccharin in short-term genotoxicity assays. Mutat. Res. Rev. Genet. 1989, 221, 69-132. [CrossRef]

16. Graf, U.; Wurgler, F.E.; Katz, A.J.; Frei, H.; Juon, H.; Hall, C.B.; Kale, P.G. Somatic mutation and recombination test in Drosophila melanogaster. Environ. Mutagen. 1984, 6, 153-188. [CrossRef]

17. Rojas Molina, M.; Campos Sánchez, J.; Analla, M.; Muñoz Serrano, A.; Alonso Moraga, A. Genotoxicity of vegetable cooking oils in the Drosophila wing spot test. Environ. Mol. Mutag. 2005, 45, 90-95. [CrossRef] [PubMed]

18. Graf, U.; Abraham, S.K.; Guzman-Rincon, J.; Wurgler, F.E. Antigenotoxicity studies in Drosophila melanogaster. Mutat. Res. 1998, 402, 203-209. [CrossRef]

19. Fernandez-Bedmar, Z.; Anter, J.; de La Cruz-Ares, S.; Munoz-Serrano, A.; Alonso-Moraga, A.; Perez-Guisado, J. Role of citrus juices and distinctive components in the modulation of degenerative processes: Genotoxicity, antigenotoxicity, cytotoxicity, and longevity in Drosophila. J. Toxicol. Environ. Health A 2011, 74, 1052-1066. [CrossRef] [PubMed]

20. Bell, R.; Hubbard, A.; Chettier, R.; Chen, D.; Miller, J.P.; Kapahi, P.; Tarnopolsky, M.; Sahasrabuhde, S.; Melov, S.; Hughes, R.E. A human protein interaction network shows conservation of aging processes between human and invertebrate species. PLoS Genet. 2009, 5, e1000414. [CrossRef]

21. Li, S.; Chen, K.; Li, X.; Zhang, X.; Liu, S.V. A new cultivation system for studying chemical effects on the lifespan of the fruit fly. Exp. Gerontol. 2010, 45, 158-162. [CrossRef] [PubMed]

22. Olive, P.L.; Frazer, G.; Banath, J.P. Radiation-induced apoptosis measured in tk6-human b-lymphoblast cells using the comet assay. Radiat. Res. 1993, 136, 130-136. [CrossRef] [PubMed]

23. Collins, A.R. The comet assay for DNA damage and repair: Principles, applications, and limitations. Mol. Biotechnol. 2004, 26, 249-261. [CrossRef]

24. Anter, J.; Demyda-Peyras, S.; Delgado-Torre, M.P.; Campos-Sanchez, J.; Luque De Castro, M.D.; Muñoz-Serrano, A.; AlonsoMoraga, Á. Biological and health promoting activity of vinification byproducts produced in Spanish vineyards. S. Afr. J. Enol. Vitic. 2015, 36, 126-133. [CrossRef]

25. Yan, J.; Huen, D.; Morely, T.; Johnson, G.; Gubb, D.; Roote, J.; Adler, P.N. The multiple-wing-hairs gene encodes a novel GBD-FH3 domain-containing protein that functions both prior to and after wing hair initiation. Genetics 2008, 180, 219-228. [CrossRef] [PubMed] 
26. Ren, N.; Charlton, J.; Adler, P.N. The flare gene, which encodes the AIP1 protein of Drosophila, functions to regulate F-actin disassembly in pupal epidermal cells. Genetics 2007, 176, 2223-2234. [CrossRef]

27. Lehkozivova, J.; Karovicova, J.; Kohajdova, Z.; Suhaj, M.; Simonova, I. Isotachophoretic analysis of the artificial sweeteners and time-intensity sweetness evaluation of soft drinks. Żywność Nauka Technol. Jakość 2006, 3, 76-85.

28. Romero-Jiménez, M.; Campos-Sánchez, J.; Analla, M.; Muñoz-Serrano, A.; Alonso-Moraga, A. Genotoxicity and anti-genotoxicity of some traditional medicinal herbs. Mutat. Res. Genet. Toxicol. Environ. Mutagen. 2005, 585, 47-155. [CrossRef]

29. Tasset-Cuevas, I.; Fernandez-Bedmar, Z.; Lozano-Baena, M.D.; Campos-Sanchez, J.; de Haro-Bailon, A.; Munoz-Serrano, A.; Alonso-Moraga, A. Protective effect of borage seed oil and gamma linolenic acid on DNA: In vivo and in vitro studies. PLoS ONE 2013, 8, e56986. [CrossRef] [PubMed]

30. Frei, H.; Wurgler, F.E. Optimal experimental design and sample size for the statistical evaluation of data from somatic mutation and recombination tests (SMART) in Drosophila. Mutat. Res. 1995, 334, 247-258. [CrossRef]

31. Anter, J.; Fernandez-Bedmar, Z.; Villatoro-Pulido, M.; Demyda-Peyras, S.; Moreno-Millan, M.; Alonso-Moraga, A.; MunozSerrano, A.; Luque de Castro, M.D. A pilot study on the DNA-protective, cytotoxic, and apoptosis-inducing properties of olive-leaf extracts. Mutat. Res. 2011, 723, 165-170. [CrossRef] [PubMed]

32. Abraham, S.K. Antigenotoxicity of coffee in the Drosophila assay for somatic mutation and recombination. Mutagenesis 1994,9 , 383-386. [CrossRef] [PubMed]

33. Anter, J.; Tasset, I.; Demyda-Peyras, S.; Ranchal, I.; Moreno-Millan, M.; Romero-Jimenez, M.; Muntane, J.; Luque de Castro, M.D.; Munoz-Serrano, A.; Alonso-Moraga, A. Evaluation of potential antigenotoxic, cytotoxic and proapoptotic effects of the olive oil by-product "alperujo", hydroxytyrosol, tyrosol and verbascoside. Mutat. Res. Genet. Toxicol. Environ. Mutagen. 2014, 772, 25-33. [CrossRef] [PubMed]

34. Mateo-Fernández, M.; Merinas-Amo, T.; Moreno-Millán, M.; Alonso-Moraga, Á.; Demyda-Peyrás, S. In vivo and in vitro genotoxic and epigenetic effects of two types of cola beverages and caffeine: A multiassay approach. BioMed Res. Int. 2016, 2016. [CrossRef]

35. Gyori, B.M.; Venkatachalam, G.; Thiagarajan, P.S.; Hsu, D.; Clement, M.V. OpenComet: An automated tool for comet assay image analysis. Redox Biol. 2014, 2, 457-465. [CrossRef]

36. Merinas-Amo, T.; Tasset-Cuevas, I.; Díaz-Carretero, A.M.; Alonso-Moraga, A.; Calahorro, F. Role of Choline in the Modulation of Degenerative Processes: In Vivo and In Vitro Studies. J. Med. Food 2017, 20, 223-234. [CrossRef]

37. Weisenberger, D.J.; Campan, M.; Long, T.I.; Kim, M.; Woods, C.; Fiala, E.; Ehrlich, M.; Laird, P.W. Analysis of repetitive element DNA methylation by MethyLight. Nucleic Acids Res. 2005, 33, 6823-6836. [CrossRef]

38. Nikolaidis, G.; Raji, O.Y.; Markopoulou, S.; Gosney, J.R.; Bryan, J.; Warburton, C.; Walshaw, M.; Sheard, J.; Field, J.K.; Liloglou, T. DNA methylation biomarkers offer improved diagnostic efficiency in lung cancer. Cancer Res. 2012, 72, 5692-5701. [CrossRef]

39. Liloglou, T.; Bediaga, N.G.; Brown, B.R.; Field, J.K.; Davies, M.P. Epigenetic biomarkers in lung cancer. Cancer Lett. 2014, 342, 200-212. [CrossRef]

40. Martínez Becerra, R.; Robles González, J. Methodology for the desing of bioassays in aquatic toxicity. Agron. Colombiana 1999, 16, 40-45.

41. Frei, H.; Wurgler, F.E. Statistical methods to decide whether mutagenicity test data from Drosophila assays indicate a positive, negative, or inconclusive result. Mutat. Res. 1988, 203, 297-308. [CrossRef]

42. Karstadt, M. Inadequate toxicity tests of food additive acesulfame. Int. J. Occup. Environ. Health. 2010, 16, 89-96. [CrossRef] [PubMed]

43. Jung, R.; Kreiling, R.; Acesulfame, K. Edited by Mayer and Kemper. Marcel Dekker 1991, 35, 87-104.

44. Mukherjee, A.; Chakrabarti, J. In vivo cytogenetic studies on mice exposed to acesulfame-K-A non-nutritive sweetener. Food Chem. Toxicol. 1997, 35, 1177-1179. [CrossRef]

45. Mayer, D. Acesulfame-K; CRC Press: Boca Ratón, FL, USA, 1991; p. 47.

46. Reuzel, P.; van der Heijden, C. Long-Term Oral Toxicity Study with Acesulfame-K in Beagles. Marcel Dekker 1991, 6, 71.

47. Butchko, H.H.; Stargel, W.W.; Comer, C.P.; Mayhew, D.A.; Benninger, C.; Blackburn, G.L.; de Sonneville, L.M.; Geha, R.S.; Hertelendy, Z.; Koestner, A. Aspartame: Review of safety. Regul. Toxicol. Pharmacol. 2002, 35, S1-S93. [CrossRef]

48. von Rymon Lipinski, G.-W.; Hanger, L.Y.; Acesulfame, K. Alternative Seeteners. In Food Science and Technology, 3rd ed.; Marcel Dekker: New York, NY, USA, 2001; pp. 13-30.

49. Bandyopadhyay, A.; Ghoshal, S.; Mukherjee, A. Genotoxicity testing of low-calorie sweeteners: Aspartame, acesulfame-K, and saccharin. Drug Chem. Toxicol. 2008, 31, 447-457. [CrossRef]

50. Martins, M.R.I.; Azoubel, R. Effects of aspartame on fetal kidney: A morphometric and stereological study. Int. J. Morphol. 2007, 25, 689-694. [CrossRef]

51. Simintzi, I.; Schulpis, K.H.; Angelogianni, P.; Liapi, C.; Tsakiris, S. The effect of aspartame on acetylcholinesterase activity in hippocampal homogenates of suckling rats. Pharmacol. Res. 2007, 56, 155-159. [CrossRef]

52. Lindseth, G.N.; Coolahan, S.E.; Petros, T.V.; Lindseth, P.D. Neurobehavioral effects of aspartame consumption. Res. Nurs. Health 2014, 37, 185-193. [CrossRef]

53. Siddique, Y.H.; Anjum, S.; Jyoti, S. Evaluation of the toxic potential of aspartame in third instar larvae of transgenic Drosophila melanogaster (hsp70-lacZ) Bg9. All Results J. Biol. 2017, 8, 16-24. 
54. Shankar, P.; Ahuja, S.; Sriram, K. Non-nutritive sweeteners: Review and update. Nutrition 2013, 29, 1293-1299. [CrossRef] [PubMed]

55. Weerasooriyagedara, M. Toxicity effects of aspartame on embryonic development of Zebrafish (Danio rerio). Int. J. Eng. Manag. Res. 2018, 8, 183-188.

56. Taylor, J.D.; Richards, R.K.; Wiegand, R.G.; Weinberg, M.S. Toxicological studies with sodium cyclamate and saccharin. Food Cosmet. Toxicol. 1968, 6, 313-327. [CrossRef]

57. Brantom, P.G.; Gaunt, I.F.; Grasso, P. Long-term toxicity of sodium cyclamate in mice. Food Cosmet. Toxicol. 1973, 11, 735-746. [CrossRef]

58. Serra-Majem, L.; Bassas, L.; García-Glosas, R.; Ribas, L.; Inglés, C.; Casals, I.; Saavedra, P.; Renwick, A.G. Cyclamate intake and cyclohexylamine excretion are not related to male fertility in humans. Food Addit. Contam. 2003, 20, 1097-1104. [CrossRef]

59. Brusick, D.; Cifone, M.; Young, R.; Benson, S. Assessment of the genotoxicity of calcium cyclamate and cyclohexylamine. Environ. Mol. Mutag. 1989, 14, 188-199. [CrossRef]

60. Bopp, B.A.; Sonders, R.C.; Kesterson, J.W.; Renwick, A. Toxicological aspects of cyclamate and cyclohexylamine. Crit. Rev. Toxicol. 1986, 16, 213-306. [CrossRef]

61. Martins, A.T.; Santos, S.F.; Scannavino, F.L.F.; Pires, J.R.; Zuza, E.P.; Padovani Junior, J.A.; Azoubel, R.; Mateo, M.A.S.D.; Lopes, R.A. Effect of sodium cyclamate on the rat fetal exocrine pancreas: A karyometric and stereological study. Int. J. Morphol. 2010, 28, 899-904. [CrossRef]

62. Chen, Z.; Chen, G.; Zhou, K.; Zhang, P.; Ren, X.; Mei, X. Toxicity of food sweetener-sodium cyclamate on osteoblasts cells. Biochem. Biophys. Res. Commun. 2019, 508,507-511. [CrossRef]

63. Hu, Y.; Xie, M.; Wu, X. Interaction studies of sodium cyclamate with DNA revealed by spectroscopy methods. Spectrochim. Acta A Mol. Biomol. Spectrosc. 2019, 220, 117085. [CrossRef] [PubMed]

64. Marquadt, H.; Marquadt, H. Induction of malignant transformation and mutagenesis in cell cultures by cancer chemothcrapeutic agents. Cancer 1977, 40, 1930-1934. [CrossRef]

65. Jung, R.; Hollander, H. Sunett. Study of the mutagenic potential in strains of Salmonella typhimurium (Ames test) and Escherichia coli. Pharm. Res. Toxicol. Unpublished Report No. 86.0811. 1986.

66. Rencüzoğulları, E.; Tüylü, B.A.; Topaktaş, M.; Ila, H.B.; Kayraldız, A.; Arslan, M.; Diler, S.B. Genotoxicity of aspartame. Drug Chem. Toxicol. 2004, 27, 257-268. [CrossRef]

67. Soffritti, M.; Belpoggi, F.; Tibaldi, E.; Degli Esposti, D.; Lauriola, M. Life-span exposure to low doses of aspartame beginning during prenatal life increases cancer effects in rats. Environ. Health Perspect. 2007, 115, 1293. [CrossRef]

68. AlSuhaibani, E.S. In vivo cytogenetic studies on aspartame. Comp. Funct. Genom. 2010, 2010, 605921. [CrossRef]

69. Elfatah, A.A.A.; Ghaly, I.S.; Hanafy, S.M. Cytotoxic effect of aspartame (diet sweet) on the histological and genetic structures of female albino rats and their offspring. Pak. J. Biol. Sci. 2012, 15, 904.

70. Kashanian, S.; Khodaei, M.M.; Kheirdoosh, F. In vitro DNA binding studies of aspartame, an artificial sweetener. J. Photochem. Photobiol. B Biol. 2013, 120, 104-110. [CrossRef] [PubMed]

71. Soffritti, M.; Belpoggi, F.; Esposti, D.D.; Lambertini, L.; Tibaldi, E.; Rigano, A. First experimental demonstration of the multipotential carcinogenic effects of aspartame administered in the feed to Sprague-Dawley rats. Environ. Health Perspect. 2006, 114, 379-385. [CrossRef]

72. Schernhammer, E.S.; Bertrand, K.A.; Birmann, B.M.; Sampson, L.; Willett, W.C.; Feskanich, D. Consumption of artificial sweetenerand sugar-containing soda and risk of lymphoma and leukemia in men and women. Am. J. Clin. Nutr. 2012, 96, 1419-1428. [CrossRef]

73. Kamath, S.; Vijaynarayana, K.; Shetty, D.P.; Shetty, P. Evaluation of genotoxic potential of aspartame. Pharmacologyonline 2010, 1, 753-769.

74. Demir, E.; Turna, F.; Aksakal, S.; Kaya, B.; Marcos, R. Genotoxicity of different sweeteners in Drosophila. Fresenius Environ. Bull. 2014, 23, 3427-3433.

75. Mohammed, M. Assessment of mutagenic potentiality of stevioside in comparison with some other sweeteners using Drosophila. AGRIS 2011.

76. Cruzan, G. Assessment of the cancer potential of methanol. Crit. Rev. Toxicol. 2009, 39, 347-363. [CrossRef] [PubMed]

77. Ahmed, F.E.; Thomas, D.B. Assessment of the carcinogenicity of the nonnutritive sweetener cyclamate. Crit. Rev. Toxicol. 1992, 22, 81-118. [CrossRef]

78. Jeffrey, A.M.; Williams, G.M. Lack of DNA-damaging activity of five non-nutritive sweeteners in the rat hepatocyte/DNA repair assay. Food Chem. Toxicol. 2000, 38, 335-338. [CrossRef]

79. Yılmaz, S.; Uçar, A. A review of the genotoxic and carcinogenic effects of aspartame: Does it safe or not? Cytotechnology 2014, 66, 875-881. [CrossRef] [PubMed]

80. Grim, J.M.; Simonik, E.A.; Semones, M.C.; Kuhn, D.E.; Crockett, E.L. The glutathione-dependent system of antioxidant defense is not modulated by temperature acclimation in muscle tissues from striped bass, Morone saxatilis. Comp. Biochem. Physiol. Part A Mol. Integr. Physiol. 2013, 164, 383-390. [CrossRef]

81. Choudhary, A.K.; Devi, R.S. Imbalance of the oxidant-antioxidant status by aspartame in the organs of immune system of Wistar albino rats. Afr. J. Biotechnol. 2014, 8, 220-230. 
82. Creppy, E.E.; Baudrimont, I.; Marie, A. How aspartame prevents the toxicity of ochratoxin A. J. Toxicol. Sci. 1998, $23,165-172$. [CrossRef]

83. Abhilash, M.; Paul, M.S.; Varghese, M.V.; Nair, R.H. Effect of long term intake of aspartame on antioxidant defense status in liver. Food Chem. Toxicol. 2011, 49, 1203-1207. [CrossRef] [PubMed]

84. Ashok, I.; Wankhar, D.; Sheeladevi, R.; Wankhar, W. Long-term effect of aspartame on the liver antioxidant status and histopathology in Wistar albino rats. Biomed. Prev. Nutr. 2014, 4, 299-305. [CrossRef]

85. Choudhary, A.K.; Devi, R.S. Longer period of oral administration of aspartame on cytokine response in Wistar albino rats Endocrinol. Nutr. 2015, 62, 114-122. [CrossRef] [PubMed]

86. Cruz-Rojas, C.; SanJuan-Reyes, N.; Fuentes-Benites, M.P.A.G.; Dublan-García, O.; Galar-Martínez, M.; Islas-Flores, H.; GómezOliván, L.M. Acesulfame potassium: Its ecotoxicity measured through oxidative stress biomarkers in common carp (Cyprinus carpio). Sci. Total Environ. 2019, 647, 772-784. [CrossRef]

87. Mchunu, N.; Chukwuma, C.I.; Ibrahim, M.A.; Oyebode, O.A.; Dlamini, S.N.; Islam, M.S. Commercially available non-nutritive sweeteners modulate the antioxidant status of type 2 diabetic rats. J. Food Biochem. 2019, 43, e12775. [CrossRef]

88. Fleming, J.E.; Reveillaud, I.; Niedzwiecki, A. Role of oxidative stress in Drosophila aging. Mutat. Res. 1992, 275, 267-279. [CrossRef]

89. Gomez, I. The Effect of Aspartame \& Sodium Nitrite on Drosophila melanogaster. In Proceedings of the AAAS 2015 Annual Meeting, San Jose, CA, USA, 12-16 February 2015.

90. Soffritti, M.; Belpoggi, F.; Manservigi, M.; Tibaldi, E.; Lauriola, M.; Falcioni, L.; Bua, L. Aspartame administered in feed, beginning prenatally through life span, induces cancers of the liver and lung in male Swiss mice. Am. J. Ind. Med. 2010, 53, 1197-1206. [CrossRef]

91. Huang, D. The Effect of Acesulfame Potassium on Phosphoinositide 3-Kinase-Induced Viability and Lifespan in Drosophila melanogaster. Acesulfame Potassium Drosoph. Melanogaster 2011, 1-26.

92. Lee, K.P.; Simpson, S.J.; Clissold, F.J.; Brooks, R.; Ballard, J.W.O.; Taylor, P.W.; Soran, N.; Raubenheimer, D. Lifespan and reproduction in Drosophila: New insights from nutritional geometry. Proc. Natl. Acad. Sci. USA 2008, 105, 2498-2503. [CrossRef]

93. Anbara, H.; Sheibani, M.T.; Razi, M. Long-term effect of aspartame on male reproductive system: Evidences for testicular histomorphometrical, Hsp70-2 protein expression and biochemical status. Int. J. Fertil. Steril. 2019, 14, 91-101.

94. Dalderup, L.; Visser, W. Influence of extra sucrose, fats, protein and of cyclamate in the daily food on the life-span of rats. Experientia 1971, 27, 519-521. [CrossRef]

95. Findikli, Z.; Turkoglu, S. Determination of the effects of some artificial sweeteners on human peripheral lymphocytes using the comet assay. J. Toxicol. Environ. Health Part A 2014, 6, 147-153.

96. Pandurangan, M.; Enkhtaivan, G.; Mistry, B.; Chandrasekaran, M.; Noorzai, R.; Kim, D.H. Investigation of role of aspartame on apoptosis process in HeLa cells. Saudi J. Biol. Sci. 2016, 23, 503-506. [CrossRef] [PubMed]

97. Oyama, Y.; Sakai, H.; Arata, T.; Okano, Y.; Akaike, N.; Sakai, K.; Noda, K. Cytotoxic effects of methanol, formaldehyde, and formate on dissociated rat thymocytes: A possibility of aspartame toxicity. Cell Biol. Toxicol. 2002, 18, 43-50. [CrossRef] [PubMed]

98. Whitcutt, J.; Bey, E. Toxicity evaluation of synthetic food sweeteners by means of the Weaver Human Cell Test. S. Afr. J. Sci. 2008, 104, 36.

99. Forchhammer, L.; Ersson, C.; Loft, S.; Möller, L.; Godschalk, R.W.; van Schooten, F.J.; Jones, G.D.; Higgins, J.A.; Cooke, M.; Mistry, V. Inter-laboratory variation in DNA damage using a standard comet assay protocol. Mutagenesis 2012, 27, 665-672. [CrossRef]

100. Yedjou, C.; Tchounwou, P. In-vitro cytotoxic and genotoxic effects of arsenic trioxide on human leukemia (HL-60) cells using the MTT and alkaline single cell gel electrophoresis (Comet) assays. Mol. Cell Biochem. 2007, 301, 123-130. [CrossRef]

101. Olive, P.L.; Banáth, J.P. The comet assay: A method to measure DNA damage in individual cells. Nat. Protoc. 2006, 1, 23-29. [CrossRef]

102. Fabiani, R.; Rosignoli, P.; De Bartolomeo, A.; Fuccelli, R.; Morozzi, G. Genotoxicity of alkene epoxides in human peripheral blood mononuclear cells and HL60 leukaemia cells evaluated with the comet assay. Mutat. Res. 2012, 747, 1-6. [CrossRef]

103. Fairbairn, D.W.; O'Neill, K.L. Necrotic DNA degradation mimics apoptotic nucleosomal fragmentation comet tail length. In Vitro Cell. Dev. Biol. Anim. 1995, 31, 171-173. [CrossRef]

104. Nakao, H.; Umebayashi, C.; Nakata, M.; Nishizaki, Y.; Noda, K.; Okano, Y.; Oyama, Y. Formaldehyde-induced shrinkage of rat thymocytes. J. Pharmacol. Sci. 2003, 91, 83-86. [CrossRef]

105. Horio, Y.; Sun, Y.; Liu, C.; Saito, T.; Kurasaki, M. Aspartame-induced apoptosis in PC12 cells. Environ. Toxicol. Pharmacol. 2014, 37, 158-165. [CrossRef] [PubMed]

106. Durnev, A.D.; Oreshchenko, A.V.; Kulakova, A.V.; Beresten, N.F.; Seredenin, S.B. Clastogenic activity of dietary sugar substitutes. Vopr. Med. Khim. 1995, 41, 31-33. [PubMed]

107. Knaap, A.G.A.C.; Kramers, P.G.N.; Sobels, F.H. Lack of mutagenicity of the cyclamate metabolites in Drosophila. Mutat. Res. Sect. Environ. Mutagen. Relat. Subj. 1973, 21, 341-344. [CrossRef]

108. Sasaki, Y.F.; Kawaguchi, S.; Kamaya, A.; Ohshita, M.; Kabasawa, K.; Iwama, K.; Taniguchi, K.; Tsuda, S. The comet assay with 8 mouse organs: Results with 39 currently used food additives. Mutat. Res. Genet. Toxicol. Environ. Mutagen. 2002, 519, 103-119. [CrossRef]

109. van Eyk, A.D. The effect of five artificial sweeteners on Caco-2, HT-29 and HEK-293 cells. Drug Chem. Toxicol. 2015, 38, 318-327. [CrossRef] [PubMed] 
110. Abdulfattah, S.Y. Studying some Cytotoxic Parameters of Aspartame (Diet sweet) on Mature Albino Male Mice. J. Biotech. Res. Center 2017, 11, 41-44. [CrossRef]

111. Murray, A.B.; Lomelino, C.L.; Supuran, C.T.; McKenna, R. "Seriously Sweet": Acesulfame K Exhibits Selective Inhibition Using Alternative Binding Modes in Carbonic Anhydrase Isoforms. J. Med. Chem. 2018, 61, 1176-1181. [CrossRef]

112. Lopez-Serra, L.; Esteller, M. Proteins that bind methylated DNA and human cancer: Reading the wrong words. Br. J. Cancer 2008, 98, 1881-1885. [CrossRef]

113. Qin, T.; Jelinek, J.; Si, J.; Shu, J.; Issa, J.-P.J. Mechanisms of resistance to 5-aza-2'-deoxycytidine in human cancer cell lines. Blood 2009, 113, 659-667. [CrossRef] [PubMed]

114. Wild, L.; Flanagan, J.M. Genome-wide hypomethylation in cancer may be a passive consequence of transformation. Biochim. Biophys. Acta Rev. Cancer 2010, 1806, 50-57. [CrossRef] [PubMed]

115. Waye, J.; Willard, H. Structure, organization, and sequence of alpha satellite DNA from human chromosome 17: Evidence for evolution by unequal crossing-over and an ancestral pentamer repeat shared with the human X chromosome. Mol. Cell. Biol. 1986, 6, 3156-3165. [PubMed]

116. Lander, E.S.; Linton, L.M.; Birren, B.; Nusbaum, C.; Zody, M.C.; Baldwin, J.; Devon, K.; Dewar, K.; Doyle, M.; FitzHugh, W. Initial sequencing and analysis of the human genome. Nature 2001, 409, 860-921.

117. Martínez, J.G.; Pérez-Escuredo, J.; Castro-Santos, P.; Marcos, C.Á.; Pendás, J.L.L.; Fraga, M.F.; Hermsen, M.A. Hypomethylation of LINE-1, and not centromeric SAT- $\alpha$, is associated with centromeric instability in head and neck squamous cell carcinoma. Cell. Oncol. 2012, 35, 259-267. [CrossRef]

118. Wilson, A.S.; Power, B.E.; Molloy, P.L. DNA hypomethylation and human diseases. Biochim. Biophys. Acta Rev. Cancer 2007, 1775, 138-162. [CrossRef]

119. Ting, D.T.; Lipson, D.; Paul, S.; Brannigan, B.W.; Akhavanfard, S.; Coffman, E.J.; Contino, G.; Deshpande, V.; Iafrate, A.J.; Letovsky, S. Aberrant overexpression of satellite repeats in pancreatic and other epithelial cancers. Science 2011, 331, 593-596. [CrossRef]

120. Schiffman, S.S. Rationale for further medical and health research on high-potency sweeteners. Chem. Senses 2012, 37, 671-679. [CrossRef] 